ARTICLE

https://doi.org/10.1038/s41467-019-12287-2

\title{
A synthetic metabolic network for physicochemical homeostasis
}

Tjeerd Pols ${ }^{1,2}$, Hendrik R. Sikkema ${ }^{1,2}$, Bauke F. Gaastra,2, Jacopo Frallicciardi ${ }^{1}$, Wojciech M. Śmigiel (iD ${ }^{1}$, Shubham Singh ${ }^{1} \&$ Bert Poolman (1) ${ }^{1}$

One of the grand challenges in chemistry is the construction of functional out-of-equilibrium networks, which are typical of living cells. Building such a system from molecular components requires control over the formation and degradation of the interacting chemicals and homeostasis of the internal physical-chemical conditions. The provision and consumption of ATP lies at the heart of this challenge. Here we report the in vitro construction of a pathway in vesicles for sustained ATP production that is maintained away from equilibrium by control of energy dissipation. We maintain a constant level of ATP with varying load on the system. The pathway enables us to control the transmembrane fluxes of osmolytes and to demonstrate basic physicochemical homeostasis. Our work demonstrates metabolic energy conservation and cell volume regulatory mechanisms in a cell-like system at a level of complexity minimally needed for life.

\footnotetext{
${ }^{1}$ Department of Biochemistry, Groningen Biomolecular Sciences and Biotechnology Institute \& Zernike Institute for Advanced Materials, University of Groningen, Nijenborgh 4, 9747 AG Groningen, The Netherlands. ${ }^{2}$ These authors contributed equally: Tjeerd Pols, Hendrik R. Sikkema, Bauke F. Gaastra. Correspondence and requests for materials should be addressed to B.P. (email: b.poolman@rug.nl)
} 
T he generation and consumption of ATP lies at the heart of life. Complex networks of proteins, nucleic acids and small molecules sustain the essential processes of gene expression and cell division that characterize living cells, but without ATP they are non-functional. Herein lies one of the major challenges in the construction of synthetic cell-like systems. Other processes, such as achieving tunable DNA replication, efficient transcription and translation, and vesicle division ${ }^{1,2}$ are essentially secondary to the solution of a controlled energy supply. Metabolic energy conservation is a prerequisite for synthetic systems no matter how complex. Energy is critical not just for (macro)molecular syntheses but also for maintaining the cytoplasm in a state compatible with metabolism through control over $\mathrm{pH}$, ionic strength and solute composition. Here we have addressed that issue and show that we can control ATP production and ionic homeostasis in synthetic vesicles.

The bottom-up construction of synthetic cells from molecular components ${ }^{3}$ differs in concept and strategy from the top-down approach to engineer minimal cells, pioneered by the J. Craig Venter institute ${ }^{4}$. Yet, both approaches address what tasks a living cell should minimally perform and how this can be accomplished with a minimal set of components. New biochemical functions and regulatory principles will be discovered as we make progress toward constructing a minimal cell. In the field of bottom-up synthetic biology (perhaps better called synthetic biochemistry), work is progressing toward establishing new information storage systems ${ }^{5}$, replication of DNA by self-encoded proteins ${ }^{6}$, the engineering of gene and protein networks 7,8 , formation of skeletal-like networks ${ }^{9}$, biosynthesis of lipids ${ }^{10-12}$, division of vesicles ${ }^{13,14}$, development of non-lipid compartment systems ${ }^{15,16}$ and chemical homeostasis through self-replication ${ }^{17,18}$. Protein synthesis has been realized using recombinant elements ${ }^{19}$, which have been incorporated into vesicles $^{20,21}$ or water-in-oil droplets ${ }^{16}$. However, long-term sustained synthesis of chemicals is a bottleneck in the development and application of synthetic cell-like systems ${ }^{22,23}$. At the root of the poor performance of reconstituted systems are challenges that relate to sustained production of nucleotides, import of substrate(s) and export of waste product(s), control of the internal physicochemical conditions ( $\mathrm{pH}$, ionic strength, crowding) and stability of the lipid-bounded compartment, all of which require constant energy dissipation.

Inspired by the challenges of the bottom-up construction of a living cell, we focus on the development of new open vesicle systems that sustain nucleotide levels and electrochemical gradients to allow further functionalities to be integrated. ATP is especially crucial, not only as a source of metabolic energy for most biological processes, but also as a hydrotrope, influencing the viscosity and possibly the structure of the cytosol ${ }^{24}$. Energy consumption in a growing cell is dominated by polymerization reactions and maintenance processes $^{25}$, so regeneration of ATP is required to keep the cell running. Recent developments in the field of synthetic biochemistry have started to address the issue of ATP homeostasis. A cell-free molecular rheostat for control of ATP levels has been reported, employing two parallel pathways and regulation by free inorganic phosphate ${ }^{26}$, but the system has not been implemented in vesicles. Photosynthetic artificial organelles have been constructed that form ATP on the outside of small vesicles, encapsulated in giant vesicles, allowing optical control of ATP dependent reactions ${ }^{27,28}$.

Here, we present the construction of a molecular system integrated into a cell-like container with control of solute fluxes and tunable supply of energy to fuel ATP-requiring processes. We have equipped the vesicles with sensors for online readout of the internal ATP/ADP ratio and $\mathrm{pH}$, allowing us to conclude that the system enables long-term metabolic energy conservation and physicochemical homeostasis.

\section{Results}

A system for sustained production of ATP. The conversion of arginine into ornithine, ammonia plus carbon dioxide yields ATP in three enzymatic steps (Fig. 1a) ${ }^{29}$. For sustainable energy conservation in a compartmentalized system, the import of substrates and excretion of products have to be efficient, which can be achieved by coupling the solute fluxes. The antiporter ArcD2 facilitates the stoichiometric exchange of the substrate arginine for the product ornithine (Fig. 1b) ${ }^{30}$, which is important for maintaining the metabolic network away from equilibrium. The thermodynamics of the arginine conversion under standard conditions are given in Fig. 1c. The equilibrium constant of the conversion of citrulline plus phosphate into ornithine plus carbamoyl-phosphate is highly unfavorable, but the overall standard Gibbs free energy difference $\left(\Delta G^{0}\right)$ of the breakdown of arginine is negative. Since the actual $\Delta \mathrm{G}$ is determined by $\Delta \mathrm{G}^{0}$ and the concentration of the reactants, the antiport reaction favors an even more negative $\Delta G$ by maintaining an out-to-in gradient of arginine and in-to-out gradient of ornithine (Fig. 1d). We anticipate that $\mathrm{NH}_{3}$ and $\mathrm{CO}_{2}$ will passively diffuse out of the cell.

Engineering of the metabolic network for ATP. To construct the system for ATP regeneration, we purified and characterized arginine deiminase (ArcA), ornithine transcarbamoylase (ArcB), carbamate kinase (ArcC1), and the arginine/ornithine antiporter ArcD2. Their kinetic and molecular properties are summarized in Fig. 2a. The enzymatic network is enclosed with inorganic phosphate and $\mathrm{Mg}-\mathrm{ADP}$ in vesicles composed of synthetic lipids, while ArcD2 is reconstituted in the membrane. The concentration and number of reporters, ions and metabolites per vesicle is given in Table 2. The lipid composition of the vesicles is based on general requirements for membrane transport (bilayer and nonbilayer-forming lipids, anionic and zwitterionic lipids), which is tuned to our needs (see below; ref. ${ }^{31}$ ). The vesicles obtained by extrusion through 400 and $200 \mathrm{~nm}$ filters have an average radius of $84 \mathrm{~nm}(\mathrm{SD}=59 \mathrm{~nm} ; n=2090)$ and $64 \mathrm{~nm}(\mathrm{SD}=39 \mathrm{~nm} ; n=$ 2092), respectively (Fig. 2b and Supplementary Fig. 1), as estimated from cryo-electron microscopy images. The average internal volumes of the vesicles center around radii of $226 \mathrm{~nm}$ $(\mathrm{SD}=113 \mathrm{~nm})$ and $123 \mathrm{~nm}(\mathrm{SD}=49 \mathrm{~nm})$, respectively (Fig. $2 \mathrm{c})$. Although a fraction of the vesicles is multi-lamellar, it is likely that all layers of the vesicles are active because we reconstitute the membrane proteins in liposomes prior to the inclusion of the enzymes, sensors and metabolites (protocol A1). The encapsulation of the luminal components is done by five freeze-thaw cycles, which induce content exchange between vesicles and homogenize the membranes. The vesicles obtained by extrusion through 200 $\mathrm{nm}$ filters are more homogenous in size (Fig. 2b, c) but contain a smaller number of components (Fig. 2a and Table 2), yet the performance of the metabolic network is similar in both types of compartments (see below).

We first characterized ArcD2 in lipid vesicles without the enzymatic network and demonstrated exchange of arginine for ornithine (Fig. 2d). ArcD2 transports arginine in and ornithine out in both membrane orientations, which is a property of this type of secondary transporter. The direction of transport is determined by the concentration gradients of the amino acids, not by the orientation of the protein. The arginine/ornithine antiport reaction is not affected by an imposed membrane potential $(\Delta \Psi)$ (Fig. 2d, inset). Surprisingly, we also detect that ArcD2 exchanges arginine for citrulline, albeit at a much lower rate than the arginine/ornithine antiport (Fig. 2e). The arginine/ 


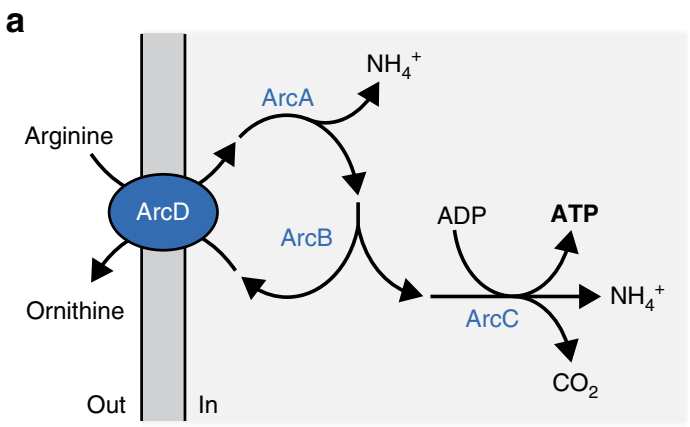<smiles>N=C(N)NCCC[C@H](N)C(=O)[O-]</smiles><smiles>NC(=O)NCCC[C@H](N)C(=O)[O-]</smiles>
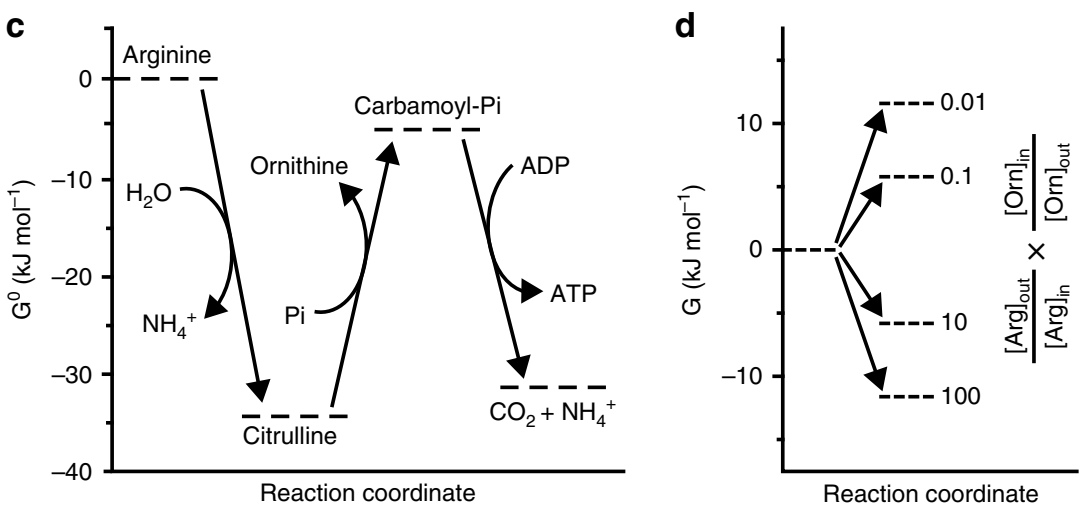

Fig. 1 Layout and thermodynamics of the system. a Schematic representation of the arginine breakdown pathway. $\mathbf{b}$ Structures of arginine, citrulline and ornithine at neutral $\mathrm{pH}$. c Thermodynamics of arginine conversion for the reactions of $\mathrm{ArcA}, \operatorname{ArcB}$, and $\operatorname{ArcC} 1 . \mathrm{G}^{0}$ values were calculated for $\mathrm{pH} 7.0$ and an ionic strength of $0.1 \mathrm{M}$ using eQuilibrator 2.2. $\mathbf{d}$ Thermodynamics of the arginine/ornithine antiport reaction. $\mathrm{G}$ values were calculated at varying concentration gradients of arginine (outside to inside) and ornithine (inside to outside). When the arginine and ornithine gradients are opposite, that is, $[\mathrm{Arg}]_{\text {in }}<[\mathrm{Arg}]_{\text {out }}$ and $[\mathrm{Orn}]_{\text {in }}>[\mathrm{Orn}]_{\text {out }}$, then a negative (and thus favorable) G value is obtained. Four scenarios for the product of the arginine and ornithine gradients are indicated

citrulline antiport is electrogenic (Fig. 2e, inset), which agrees with arginine (and ornithine) being cationic and citrulline being neutral at pH 7 (Fig. 1b).

The turnover number $\left(k_{\mathrm{cat}}\right)$ and equilibrium constant $\left(K_{\mathrm{eq}}\right)$ of the enzymes were used to guide the initial design of the pathway, and the enzymes were incorporated in the vesicles at a copy number well above the stochastic threshold (Fig. 2a). The ArcD2 protein is reconstituted at a lipid-to-protein ratio of 400:1 (w/w), yielding on average 62 and 19 antiporters per vesicle with radii of 226 and $123 \mathrm{~nm}$, respectively. Since arginine is imported when a counter solute is present on the inside, we include L-ornithine in the vesicles to enable the metabolism of arginine. For readout of ATP production, we enclosed PercevalHR ${ }^{32}$, a protein-based fluorescent reporter of the ATP/ADP ratio (Fig. 3a); the calibration and characterization of the sensor are shown in Supplementary Fig. 2. Upon addition of arginine, the vesicles produce ATP. Thus, after an initial, rapid, increase in the ratio of the excitation maxima at $500 \mathrm{~nm}$ and $430 \mathrm{~nm}$ (representing an increase in ATP/ADP ratio) the ratio unexpectedly declines after 30 min (Fig. 3b, blue trace). The ATP/ADP ratio increases again and stabilizes (Fig. 3b, black trace) in the presence of the protonophore carbonyl cyanide-4-(trifluoromethoxy) phenylhydrazone (FCCP), suggesting that arginine conversion by the metabolic network changes the internal $\mathrm{pH}$ of the vesicles (see below). The drop in fluorescence signal without FCCP is explained by the $\mathrm{pH}$-dependent binding of nucleotides to PercevalHR (Supplementary Fig. $2 \mathrm{~b}$ and $2 \mathrm{c}$ ). The decrease in F500/430 signal suggests that the internal $\mathrm{pH}$ is decreasing, because the fluorescence of PercevalHR increases with increasing $\mathrm{pH}$ (Supplementary Fig. 2b).

We found that, in the initial design of the pathway, a substantial amount of citrulline is formed on the outside, which is due to residual binding of ArcA to the outer membrane surface even after repeated washing of the vesicles; control experiments rule out that ArcA is binding to ArcD2 or OpuA or due to a high or low concentration of anionic lipid. We thus inactivated external ArcA by treatment of the vesicles with the membraneimpermeable sulfhydryl reagent $p$-chloromercuribenzene sulfonate (pCMBS). To avoid inhibition of the antiporter ArcD2, we engineered a cysteine-less variant that is fully functional and insensitive to sulfhydryl reagents (Supplementary Fig. 3). This optimized system is used for further characterization and application.

Arginine breakdown and control of futile hydrolysis and $\mathrm{pH}$. The breakdown of arginine, in the lumen of the vesicle, is given by the reaction equation:

$$
\begin{array}{r}
\text { L-Arginine }+\mathrm{H}_{2} \mathrm{O}+\mathrm{HPO}_{4}^{2-}+\mathrm{Mg}-\mathrm{ADP}^{1-} \\
+3 \mathrm{H}^{+} \rightarrow \text { L-Ornithine }+\mathrm{Mg}-\mathrm{ATP}^{2-}+2 \mathrm{NH}_{4}^{+}+\mathrm{CO}_{2}
\end{array}
$$

The external $\mathrm{pH}$ increases upon the addition of arginine (Fig. 3c), which is in accordance with Eq. (1) when the reaction products (except for ATP) end up in the outside medium (Fig. 3d). Unexpectedly, the vesicle lumen acidifies over longer timescales, that is, after an initial increase of the internal $\mathrm{pH}$ 


\begin{tabular}{|c|c|c|c|c|c|c|c|c|c|}
\hline a & $\mathrm{K}_{\mathrm{eq}}$ & M.W. & $\begin{array}{l}\text { Oligomeric } \\
\text { state }\end{array}$ & $\begin{array}{l}\text { Internal } \\
\text { conc. }\end{array}$ & $\begin{array}{r}\text { Mole } \\
\text { per v } \\
400 \mathrm{~nm}\end{array}$ & $\begin{array}{l}\text { ules } \\
\text { sicle } \\
200 \mathrm{~nm}\end{array}$ & Substrate & $\mathrm{K}_{\mathrm{M}}$ & $\boldsymbol{k}_{\text {cat }}$ \\
\hline ArcA & $1.2 \times 10^{6}$ & $191 \mathrm{kDa}$ & Tetramer & $1 \mu \mathrm{M}$ & 28 & 5 & Arginine & $26.5 \mu \mathrm{M}$ & $12 \mathrm{~s}^{-1}$ \\
\hline ArcB & $8.5 \times 10^{-6}$ & $245 \mathrm{kDa}$ & Hexamer & $2 \mu \mathrm{M}$ & 57 & 9 & $\begin{array}{r}\text { Ornithine } \\
\text { Carbamoyl-Pi }\end{array}$ & $\begin{array}{l}0.7 \mathrm{mM} \\
1.9 \mathrm{mM}\end{array}$ & $\begin{array}{l}2300 \mathrm{~s}^{-1} \\
2900 \mathrm{~s}^{-1}\end{array}$ \\
\hline ArcC1 & $4.2 \times 10^{4}$ & $72 \mathrm{kDa}$ & Dimer & $5 \mu \mathrm{M}$ & 144 & 24 & $\begin{array}{r}\text { ADP } \\
\text { Carbamoyl-Pi }\end{array}$ & $\begin{array}{l}1.0 \mathrm{mM} \\
0.7 \mathrm{mM}\end{array}$ & $\begin{array}{l}310 \mathrm{~s}^{-1} \\
420 \mathrm{~s}^{-1}\end{array}$ \\
\hline ArcD2 & & $57 \mathrm{kDa}$ & Monomer & & 62 & 19 & $\begin{array}{r}\text { Arginine } \\
\text { Ornithine }\end{array}$ & $\begin{array}{c}4 \mu \mathrm{M} \\
29 \mu \mathrm{M}\end{array}$ & $\begin{array}{r}20 \mathrm{~s}^{-1} \\
130 \mathrm{~s}^{-1}\end{array}$ \\
\hline OpuA & & $216 \mathrm{kDa}$ & Heterodimer & & 31 & 9 & $\begin{array}{r}\text { Glycine Betaine } \\
\text { ATP }\end{array}$ & $\begin{array}{c}1.9 \mu \mathrm{M} \\
3 \mathrm{mM}\end{array}$ & $1 \mathrm{~s}^{-1}$ \\
\hline
\end{tabular}
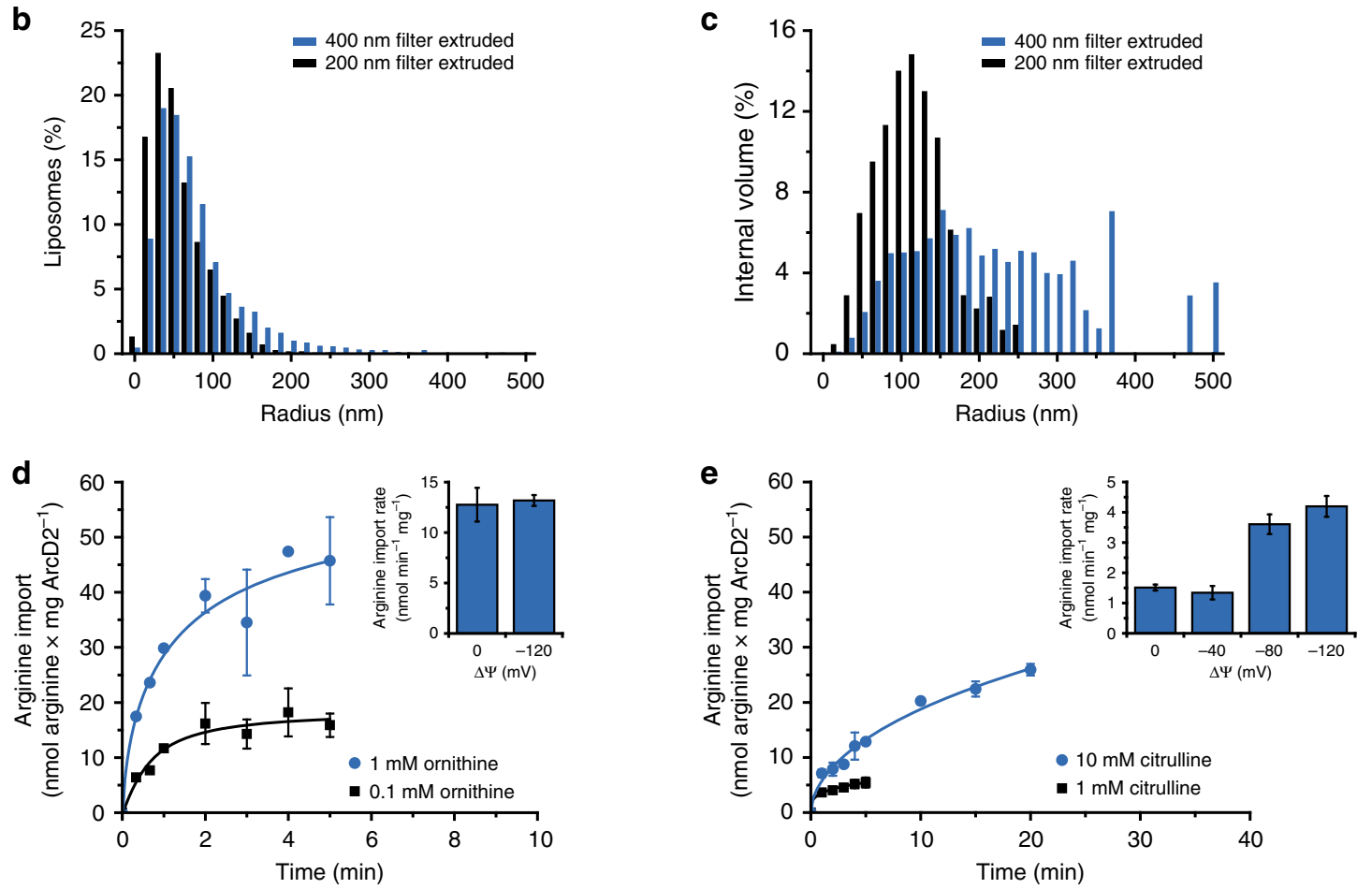

Fig. 2 Characterization of the components of the system. a Molecular and kinetic properties of the enzymes; $K_{\text {eq }}$ was calculated as in Fig. 1c. The $K_{M}$ values of a given substrate were determined under conditions of excess of the other substrate. The number of molecules per vesicle was calculated from the internal concentration of the enzymes and the average size of the vesicles, for $400 \mathrm{~nm}$ (left column) and $200 \mathrm{~nm}$ (right column) extruded vesicles. Kinetic parameters of $\mathrm{ArcB}$ are given for the back reaction. The kinetic parameters of ArcD2 were estimated from measurements in cells ${ }^{48}$, assuming that ArcD2 constitutes $1 \%$ of membrane protein; the data for OpuA are from ref. ${ }^{40}$. b Distribution of the radius of lipid vesicles extruded through a $400 \mathrm{~nm}$ (blue bars) and $200 \mathrm{~nm}$ (black bars) polycarbonate filter as estimated from CryoTEM micrographs (Supplementary Fig. 1). The diameter of 2090 vesicles (400 nm filter) and 2092 vesicles (200 nm filter) were measured using ImageJ. c Distribution of the internal volume, based on the distribution of radii, assuming that all vesicles are spherical. $\mathbf{d}$ Kinetics of arginine uptake in proteoliposomes with $1 \mathrm{mM}$ (blue circles) and $0.1 \mathrm{mM}$ (black squares) ornithine on the inside (protocol B2); ${ }^{14} \mathrm{C}$-arginine concentration of $10 \mu \mathrm{M}$. Inset: influence of a membrane potential $(\Delta \Psi)$ on arginine uptake with $1 \mathrm{mM}$ ornithine on the inside. Data from replicate experiments $(n=2)$ are shown, error bars indicate standard deviation. e Kinetics of arginine uptake in proteoliposomes with 10 mM (blue circles) and $1 \mathrm{mM}$ (black squares) citrulline on the inside (protocol B2); ${ }^{14} \mathrm{C}$-arginine concentration of $10 \mu \mathrm{M}$. Inset: influence of a membrane potential $(\Delta \Psi)$ on arginine uptake with $10 \mathrm{mM}$ citrulline on the inside $(n=2)$. Source data of are provided as a Source Data file

(Fig. 2e, blue line; pyranine calibration shown in Supplementary Fig. 4); the transient in the internal $\mathrm{pH}$ is more evident when the internal buffer capacity is decreased (Fig. 2e, black line). The acidification of the vesicle lumen cannot be readily explained if arginine is solely converted into ornithine (Eq. (1)). Indeed, we found citrulline as an end product in addition to ornithine (Fig. 4a).

What is the basis for the futile hydrolysis of arginine? Since external ArcA was inactivated by pCMBS, we infer that part of the citrulline is not metabolized further but exported and accompanied by diffusion of $\mathrm{NH}_{3}$ through the membrane. This side reaction is possible if steps in the pathway downstream of ArcA are limiting the breakdown of arginine (Fig. 4b, bold arrow) and when citrulline is exchanged for arginine (Fig. $4 \mathrm{~b}$, dashed arrow). In the vesicles with the full arginine breakdown pathway, citrulline will compete with ornithine for export, when the internal citrulline concentration is high. The equilibrium constant of the reaction catalyzed by $\operatorname{ArcB}\left(K_{\text {eq }}=8.5 \times 10^{-6}\right.$, see Fig. 2a) predicts high citrulline-to-ornithine ratios in the vesicles. Indeed, we find that the internal citrulline-to-ornithine ratio increases 
a
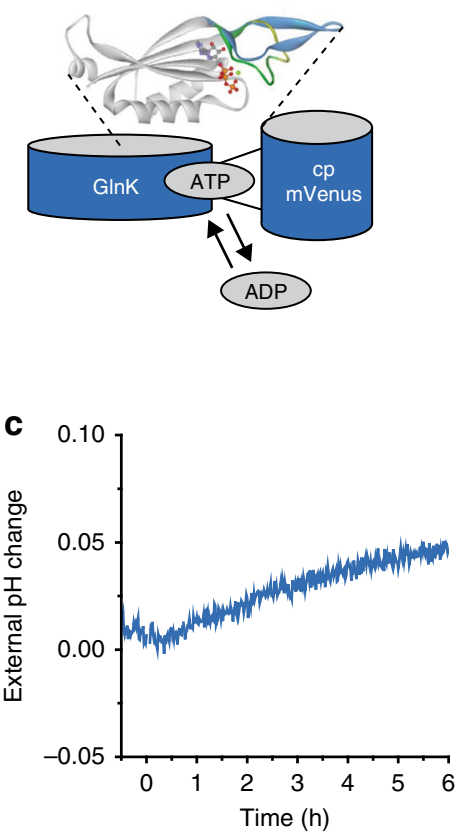

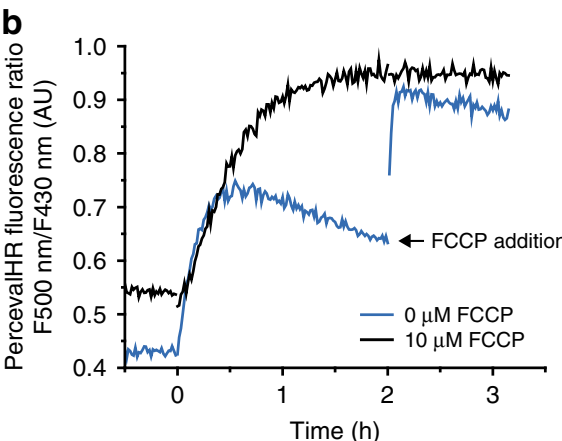

d

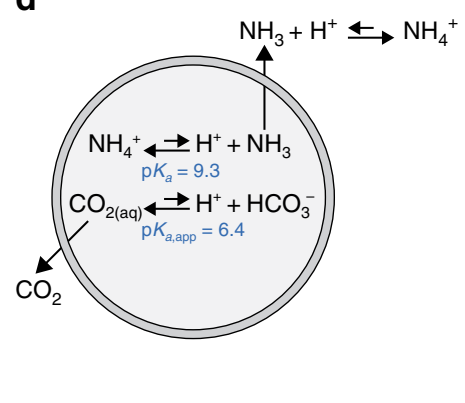

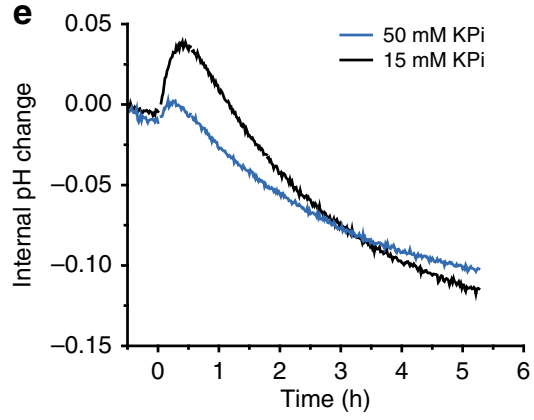

Fig. 3 Generation of ATP and pH changes. The internal composition of the vesicles at the start of the experiment is given in Fig. 2a (enzymes) and Table 2 (ions, metabolites) and the preparation of vesicles is given in protocol $A 1$, unless specified otherwise. a Schematic representation of PercevalHR; modification of cartoon in ref. ${ }^{32}$. $\mathbf{b}$ Effect of FCCP on the fluorescence readout of PercevalHR (protocol A1); the ratio of the fluorescence peaks at 500 nm and $430 \mathrm{~nm}$ is shown. In the absence of FCCP, the fluorescence readout declines $30 \mathrm{~min}$ after addition of $10 \mathrm{mM}$ arginine (at $t=0$ ) due to changes in the internal $\mathrm{pH}$ (addition of FCCP after $2 \mathrm{~h}$ increases the signal, indicated by the black arrow). The fluorescence signal is constant for several hours in the presence of $10 \mu \mathrm{M} \mathrm{FCCP}(n=2)$. c External pH change (protocol B5) of arginine-metabolizing vesicles in outside medium with $10 \mathrm{mM} \mathrm{KPi} \mathrm{pH} 7.0$ plus $355 \mathrm{mM} \mathrm{KCl}$. The ATP production was started by adding $5 \mathrm{mM}$ arginine at $t=0$. d Schematic representation of the $\mathrm{pH}$ effects caused by ammonia and carbon dioxide diffusion. e Internal pH change (protocol B4) of arginine-metabolizing vesicles with either $50 \mathrm{mM}$ (blue trace) or $15 \mathrm{mM} \mathrm{KPi}$ plus $40 \mathrm{mM}$ $\mathrm{KCl}, \mathrm{pH} 7.0$ on the inside (protocol A2; black trace). Five millimolar arginine was added at $t=0(n=2)$

from 0 to more than 10 when arginine is converted for $1 \mathrm{~h}$. Thus, the $K_{\mathrm{eq}}$ values of the reactions of citrulline formation and breakdown (Fig. 2a), and the substrate promiscuity of ArcD2 (Fig. 2d, e) enable arginine/citrulline in addition to arginine/ ornithine antiport.

How do the side reactions of the arginine breakdown pathway lead to acidification of the vesicle lumen? The $\mathrm{pK}_{\mathrm{A}}$ of $\mathrm{NH}_{4}+\leftrightarrow$ $\mathrm{NH}_{3}+\mathrm{H}^{+}$is 9.09 at $30{ }^{\circ} \mathrm{C}^{33}$, and thus at $\mathrm{pH} 7.0$ the fraction of $\mathrm{NH}_{3}$ is small, but the base/conjugated acid reaction is fast. If $\mathrm{NH}_{3}$ diffuses across the membrane, it will leave a proton behind in the vesicle lumen. Since the external volume is large compared with the internal one, there will be a net flux of $\mathrm{NH}_{3}$ from the vesicle lumen to the medium. Using stopped-flow fluorescence-based flux measurements to probe the permeability of the vesicles for small molecules, we confirmed that $\mathrm{NH}_{3}$ diffuses out rapidly, but that the membrane is highly impermeable for inorganic phosphate, $\mathrm{K}^{+}$, and $\mathrm{Cl}^{-}$ions (Fig. 4c). $\mathrm{CO}_{2}$ also diffuses rapidly across the membrane, down its concentration gradient, but only $\mathrm{NH}_{3}$ leaves behind protons, therefore it is this that causes the $\mathrm{pH}$ change in the vesicle lumen. Finally, the breakdown of arginine to ornithine plus $\mathrm{NH}_{4}^{+}$and $\mathrm{CO}_{2}$ is a dead-end process, which reaches equilibrium if the produced ATP is not utilized; the system runs out of $\mathrm{ADP}$ in about $30 \mathrm{~min}$. The production of $\mathrm{NH}_{4}{ }^{+}$from the conversion of arginine to citrulline then takes over, and the accompanying diffusion of $\mathrm{NH}_{3}$ out of the vesicles leads to a net acidification of the vesicle lumen (Fig. 4d). Indeed, in Fig. 4d we show that the vesicles acidify significantly less when the vesicles are loaded with a higher concentration of ADP and the ATP synthesis is extended.
Load on the metabolic network. Cell growth is impacted by the solute concentration of the environment. Control of osmolyte import and export under conditions of osmotic stress allows cells to maintain their volume and achieve physicochemical homeostasis $^{34-36}$. Potassium is the most abundant osmolyte in many (micro)organisms, but excessive salt accumulation increases the ionic strength, which diminishes enzyme function. To control the volume, internal $\mathrm{pH}$, and ionic strength, bacteria modulate the intake of potassium ions. When needed, they replace the electrolyte for so-called compatible solutes, like glycine betaine, proline and/or sugars ${ }^{37}$. Compatible solutes like glycine betaine not only act in volume regulation but also prevent aggregation of macromolecules by affecting protein folding and stability 38,39 .

The energy produced by the ATP breakdown pathway has been used to modulate the balance of osmolytes in the vesicles via activating the ATP-driven glycine betaine transporter OpuA (Fig. 4e). To this end we co-reconstituted OpuA with the components of the metabolic network for ATP production. OpuA transports solutes into the vesicle lumen when the protein is oriented with the nucleotide-binding domains on the inside. It happens to be that we reconstitute OpuA for more than $90 \%$ in this desired orientation 31,40 , but any protein in the opposite orientation is non-functional because ATP is only produced inside the vesicles. In vesicles with $13 \mathrm{~mol} \%$ DOPG [1,2-di-(9Zoctadecenoyl)-sn-glycero-3-phospho-(1'-rac-glycerol)] OpuA is constitutively active and imports glycine betaine at the expense of ATP (Fig. 5a), albeit at a low rate ${ }^{41}$. OpuA is ionic strength-gated and more active when sufficient levels of anionic lipids are present in the membrane ${ }^{31,41}$, which is the physiologically more 
a
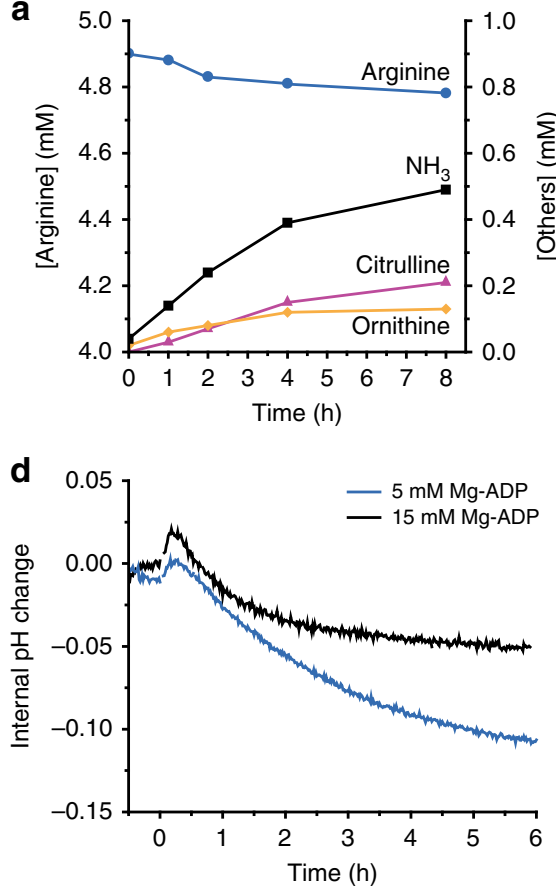

b
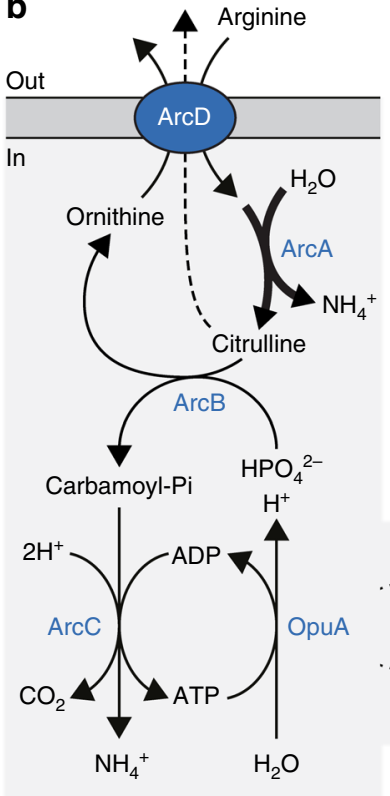

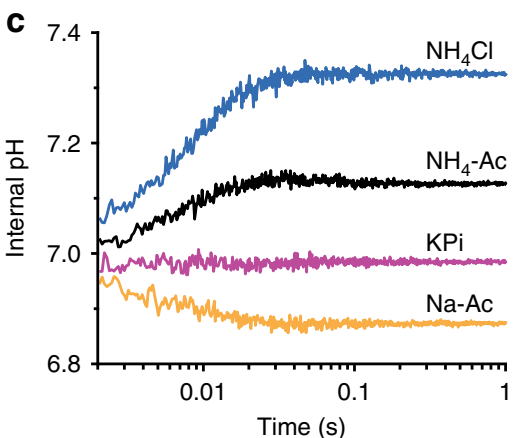

e

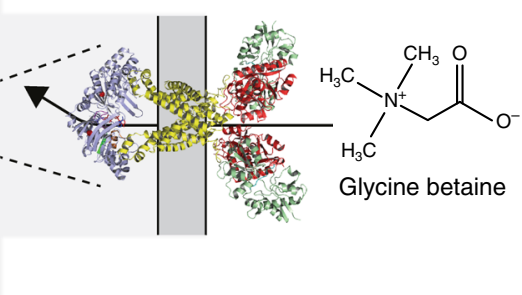

Fig. 4 Control of futile hydrolysis of arginine and pH homeostasis. The internal composition of the vesicles at the start of the experiment is given in Fig. $2 a$ (enzymes) and Table 2 (ions, metabolites) and the preparation of vesicles is given in protocol A1, unless specified otherwise. a External concentration of metabolites (protocol B6): arginine (blue circles), citrulline (pink triangles), ornithine (yellow diamonds), and $\mathrm{NH}_{3}$ (black squares), as measured by HPLC in vesicles treated with $25 \mu \mathrm{M}$ pCMBS. Five millimolar arginine was added at $t=0$. b Schematic representation of arginine breakdown; the futile hydrolysis of arginine and arginine/citrulline exchange are depicted by bold and dashed arrows, respectively. c Stopped-flow fluorescence measurements to determine the permeability of the vesicles for $\mathrm{NH}_{4} \mathrm{Cl}$ (blue trace), $\mathrm{NH}_{4}$-acetate (black trace), potassium phosphate (pink trace) and sodium acetate (yellow trace); pyranine inside the vesicles was used as $\mathrm{pH}$ indicator $(n \geq 2)$. $\mathbf{d}$ Internal $\mathrm{pH}$ change (protocol B4) of arginine-metabolizing vesicles with either $5 \mathrm{mM} \mathrm{Mg-}$ ADP (protocol A1; blue trace) or $15 \mathrm{mM} \mathrm{Mg-ADP}$ on the inside (protocol A3; black trace). Five millimolar arginine was added at $t=0$ ( $n=2$ ). e Homology model of OpuA and structure of the compatible solute glycine betaine. Glycine betaine import via OpuA consumes the ATP as indicated in (b)

a

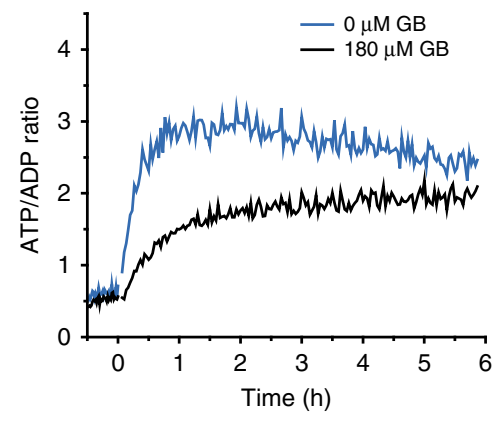

b
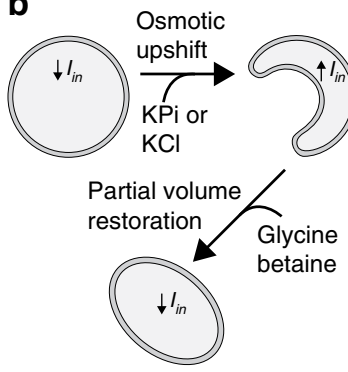

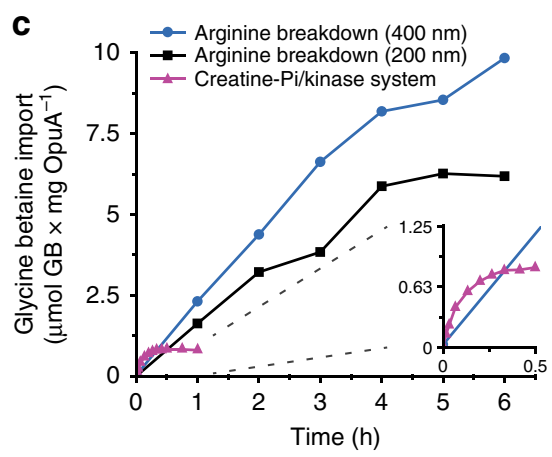

Fig. 5 ATP/ADP homeostasis and long-term transport. The internal composition of the vesicles at the start of the experiment is given in Fig. 2a (enzymes) and Table 2 (ions, metabolites) and the preparation of vesicles is given in protocol A1, unless specified otherwise. a Effect of external glycine betaine (GB) on the ATP/ADP ratio measured by PercevalHR (protocol B3) in unshocked arginine-metabolizing vesicles (made with 13 mol\% of DOPG; protocol A7), in the presence (black trace) and absence (blue trace) of $180 \mu \mathrm{M}$ glycine betaine, added at $t=-0.5 \mathrm{~h}$. Five millimolar arginine was added at $t=0$ ( $n=2$ ). b Schematic representation of the effect of osmotic upshift and partial volume restoration through glycine betaine uptake are shown. c Comparison of glycine betaine uptake (protocol B1) driven by ATP formed in the arginine breakdown pathway from $400 \mathrm{~nm}$ extruded vesicles (blue circles), $200 \mathrm{~nm}$ extruded vesicles (protocol A4; black squares), and the creatine-phosphate/kinase system (protocol A5; pink triangles) $(n=2)$

relevant situation; for this, we use $38 \mathrm{~mol} \% \mathrm{DOPG}$ and an internal ionic strength below $0.2 \mathrm{M}$ to lock OpuA in the off state. By increasing the medium osmolality with membraneimpermeant osmolytes ( $\mathrm{KPi}$ or $\mathrm{KCl}$ ), the vesicles shrink due to water efflux (Fig. 5b) until the internal osmotic balance is achieved, which occurs on the timescale of $<1 \mathrm{~s}$. Thus, the pressure exerted by the addition of $\mathrm{KPi}$ or $\mathrm{KCl}$ is dissipated by lowering the volume-to-surface ratio of the vesicles. The accompanying increase in internal ionic strength activates OpuA and glycine betaine is imported to high levels (Fig. $5 \mathrm{c}$, blue circles). The vesicles now possess an interior that is a mixture of glycine betaine and salts. The consumption of ATP by the gated import of glycine betaine is shown in Fig. 6a. Most remarkably, the gated import continues for hours when the internal ionic strength remains above the gating threshold and the $\mathrm{pH}$ is kept constant (Fig. 5c, blue circles). The open system, with arginine feed and product drain, performs at least an order of magnitude better than closed systems for ATP regeneration, where the 
a
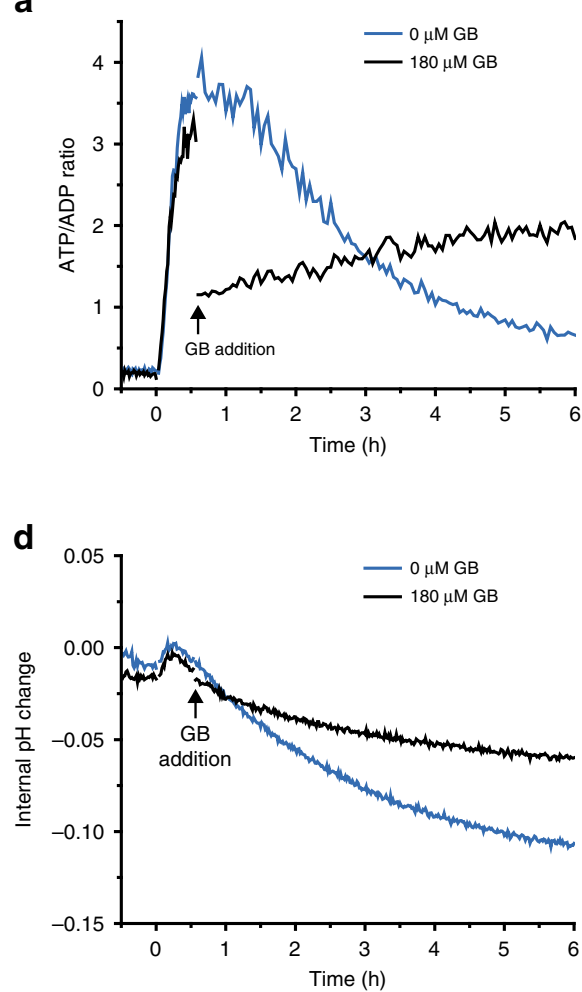

b

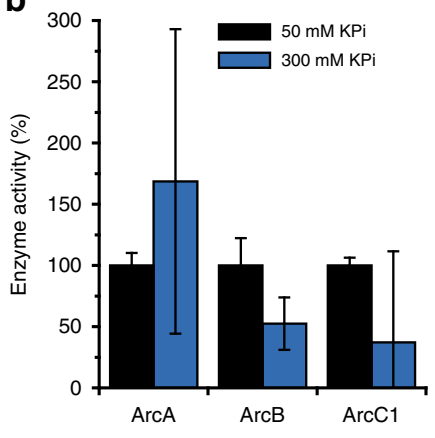

C

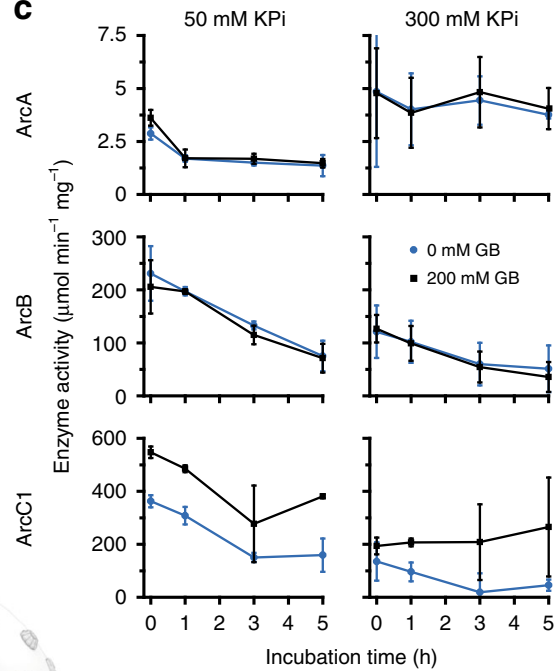

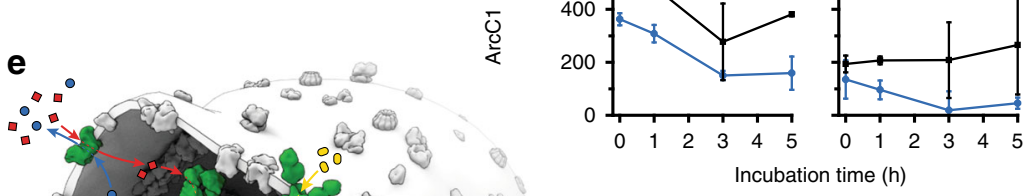

Fig. 6 Physicochemical homeostasis of arginine-metabolizing vesicles. The internal composition of the vesicles at the start of the experiment is given in Fig. 2a (enzymes) and Table 2 (ions, metabolites) and the preparation of vesicles is given in protocol A1, unless specified otherwise. a Effect of glycine betaine (GB) on the ATP/ADP ratio measured by PercevalHR (protocol B3) inside arginine-metabolizing vesicles exposed to an osmotic upshift (addition of $250 \mathrm{mM} \mathrm{KCl}$ externally) in the presence (black trace) and absence (blue trace) of $180 \mu \mathrm{M}$ glycine betaine, added at $t=0.5 \mathrm{~h}$. Five millimolar arginine was added at $t=0(n=3)$. b Activity of ArcA (left), ArcB (middle), and ArcC1 (right) in $50 \mathrm{mM} \mathrm{KPi,} \mathrm{pH} 7.0$ (black bar), and $300 \mathrm{mM} \mathrm{KPi,} \mathrm{pH} 7.0$ (blue bar) as determined from the production of citrulline (ArcA, ArcB) or ATP (ArcC1). The activities were normalized to those in $50 \mathrm{mM} \mathrm{KPi,} \mathrm{PH} 7.0$, the absolute activities are given in Supplementary Table 3; error bars indicate standard deviation ( $n=2$ ). c Stability of ArcA (top), ArcB (middle), and ArcC1 (bottom) in $50 \mathrm{mM} \mathrm{KPi}, \mathrm{pH} 7.0$ (left), and $300 \mathrm{mM} \mathrm{KPi}, \mathrm{pH} 7.0$ (right) at $30^{\circ} \mathrm{C}$, in the presence (black squares) and absence (blue circles) of 200 mM glycine betaine $(n=2)$. d Effect of glycine betaine on the internal pH measured by pyranine (protocol B4) inside arginine-metabolizing vesicles exposed to an osmotic upshift $(250 \mathrm{mM} \mathrm{KCl})$ in the presence (black trace) and absence (blue trace) of $180 \mu \mathrm{M}$ glycine betaine, added at $t=0.5 \mathrm{~h}$. Five millimolar arginine was added at $t=0(n=3)$. e Schematic representation of the synthetic metabolic network in the cell-like container with the intermediates: arginine (red squares), ornithine (blue circles), citrulline (orange triangles), carbamoyl-phosphate (pink triangles), and glycine betaine (yellow ovals). NH 3 and $\mathrm{CO}_{2}$ are not shown. Source data of are provided as a Source Data file

substrate for ATP synthesis is present on the inside and cannot be replenished, as exemplified by the creatine-phosphate/kinase system (Fig. 5c, pink triangles) ${ }^{40}$. Comparable results were obtained when smaller, yet more homogenous vesicles were formed by extrusion through $200 \mathrm{~nm}$ polycarbonate filters (Fig. 5c, black squares, see also Supplementary Fig. 5).

To determine the fraction of vesicles with a fully functional arginine breakdown pathway, we compared the rates of transport of glycine betaine in our synthetic cell system with those of OpuA vesicles containing $10 \mathrm{mM}$ of ATP. With our synthetic network transport only occurs when ATP is formed, which requires the presence of each of the enzymes well above the stochastic threshold. When the metabolic pathway reaches steady state, the ATP and ADP concentrations are about 3.3 and $1.7 \mathrm{mM}$, respectively (see Table 2, ATP/ADP ratio of 2), and under these conditions we determined the rate of transport via OpuA. The $K_{\mathrm{M}}$ value for ATP is $3 \mathrm{mM}$ and the $K_{\mathrm{I}}$ for ADP is $12 \mathrm{mM}$ (taken from ref. $\left.{ }^{42}\right)$. From these numbers we compute the $V / V_{\operatorname{MAX}}$ for transport in the synthetic vesicles. For the OpuA vesicles with $10 \mathrm{mM}$ ATP there is negligible formation of ADP when initial rates of transport are determined, and the $V / V_{\mathrm{MAX}}$ is calculated similarly. From the ratio of the $V / V_{\mathrm{MAX}}$ in the vesicles with full pathway over the $V / V_{\text {MAX }}$ in the OpuA vesicles (Fig. 5c), we obtain a lower limit for the fraction of active vesicles of $70 \%$.

Physicochemical homeostasis. Next, we tested how the physicochemical homeostasis is sustained when the vesicles are osmotically challenged. Figure 6a shows the evolution in time of the ATP/ADP ratio upon addition of arginine to vesicles that were exposed to an increased medium osmolality $30 \mathrm{~min}$ before the addition of arginine; FCCP was added to avoid $\mathrm{pH}$ effects on the readout of PercevalHR (Supplementary Fig. 2b). In the absence of glycine betaine the ATP/ADP ratio peaks at $1 \mathrm{~h}$ and decreases over the next $4-5 \mathrm{~h}$ (Fig. $6 \mathrm{a}$, blue line), which indicates the presence of futile ATP hydrolysis when the internal salt concentration is high. Intriguingly, when glycine betaine was added $0.5 \mathrm{~h}$ after arginine (Fig. $6 \mathrm{a}$, black line), the ATP/ADP ratio drops instantly, but then remains stable for $6 \mathrm{~h}$. Glycine betaine therefore has two effects: its accumulation provides a 'cytosol' that is more compatible with enzyme function (Fig. 6b, c), but it also provides a metabolic sink for ATP through its OpuAmediated transport. The decrease in ATP/ADP ratio in the absence of glycine betaine can be explained by inhibition of enzymatic activity at high ionic strength (Fig. 6b), combined with 
futile hydrolysis of ATP. Accordingly, the decrease in ATP/ADP ratio is much less in vesicles in which the ionic strength is kept low (Fig. 5a); compare Figs. 5a and 6a. Finally, we report ATP/ ADP ratios because the absolute concentrations change when the vesicles are osmotically shrunk and subsequently regain volume. In most experiments, the initial adenine nucleotide (=ADP) concentration was $5 \mathrm{mM}$ but increases when the vesicles are exposed to osmotic stress. In Fig. 5a, we report data of unshocked vesicles and here the ATP/ADP ratios of 2-3 correspond to $3.33-3.75 \mathrm{mM}$ of ATP, respectively, which is in the range of concentrations in living cells.

Importantly, the introduction of an ATP-consuming process stimulates the full pathway at the expense of citrulline formation, and hence should stabilize the internal $\mathrm{pH}$. Indeed, our results show that the system is better capable of maintaining the internal $\mathrm{pH}$ relatively constant when ATP is utilized (Fig. 6d, black line). Under these conditions the arginine-to-citrulline conversion is diminished relative to full pathway activity. We therefore propose that the stabilizing effect of glycine betaine accumulation originates from a lowering of the ionic strength (partial restoration of the vesicle volume), a chaperoning effect on the proteins and the maintenance of the internal $\mathrm{pH}$, hence reflecting what compatible solutes do in living cells ${ }^{37}$.

In summary and perspective: we present the in vitro construction of a cell-like system that maintains a metabolic state farfrom-equilibrium for many hours (Fig. 6e). This is one of the most advanced functional reconstitutions of a chemically defined network ever achieved, which allows the development of complex life-like systems with adaptive behavior in terms of lipid and protein synthesis, cell growth and intercellular communication. We show that ATP is used to fuel the gated transport of glycine betaine, which allows the synthetic vesicles to maintain a basic level of physicochemical homeostasis. We have recently postulated alternative mechanisms for metabolic energy conservation ${ }^{43}$ by coupling substrate/product antiporters to substrate decarboxylation, allowing the formation of a proton or sodium motive force. Combining such a pathway with the here-developed network for ATP would allow an even greater control of the physicochemical homeostasis.

Maintenance of the ATP/ADP ratio, internal $\mathrm{pH}$, and presumably ionic strength are crucial for any metabolic system in the emerging field of synthetic biochemistry ${ }^{23,26}$. We expect that our metabolic network will find wide use beyond membrane and synthetic biology, as biomolecular out-of-equilibrium systems will impact the development of next generation materials (e.g. delivery systems) with active, adaptive, autonomous, and intelligent behavior.

\begin{abstract}
Methods
Materials. Common chemicals were of analytical grade and ordered from SigmaAldrich Corporation, Carl Roth GmbH \& Co. KG or Merck KGaA. The lipids were obtained from Avanti Polar Lipids, Inc. (>99\% pure, in chloroform): 1,2-dioleoyl$s n$-glycero-3-phosphoethanolamine (DOPE) [850725C], 1,2-dioleoyl-sn-glycero-3phosphocholine (DOPC) [850375C], and 1,2-dioleoyl-sn-glycero-3-phospho- $\left(1^{\prime}\right.$ rac-glycerol) (DOPG) [840475C]. $n$-dodecyl- $\beta$-D-maltoside (DDM) [D97002] was purchased from Glycon Biochemicals GmbH and Triton X-100 [T9284] from Sigma-Aldrich Corporation. ${ }^{14} \mathrm{C}$-glycine betaine was prepared enzymatically from ${ }^{14} \mathrm{C}$-choline-chloride (American Radiolabeled Chemicals, Inc. [ARC 0208, $55 \mathrm{mCi}$ $\left.\mathrm{mmol}^{-1}\right]$ ) as described in ref. ${ }^{31} .{ }^{14} \mathrm{C}$-arginine was purchased from Moravek, Inc. [MC-137, $338 \mathrm{mCi} \mathrm{mmol}^{-1}$ ], ${ }^{14} \mathrm{C}$-citrulline from American Radiolabeled Chemicals, Inc. [ARC 0508, $55 \mathrm{mCi} \mathrm{mmol}^{-1}$ ], and ${ }^{3} \mathrm{H}$-ornithine hydrochloride from PerkinElmer Health Sciences, Inc. [NET1212, $21.4 \mathrm{Ci} \mathrm{mmol}^{-1}$ ].
\end{abstract}

Construction of expression strains. The $\operatorname{arcX}$ genes were PCR-amplified from the genome of Lactococcus lactis IL1403 with primers $\operatorname{arcX}-\mathrm{Fw}$ and $\operatorname{arcX}$-rev (see Supplementary Table 1), using Phusion HF DNA polymerase (Thermo Fisher Scientific, Inc.). The $\operatorname{arc} A$ and $\operatorname{arcB}$ PCR inserts, and the pNZcLICoppA vector ${ }^{44}$, were digested with $\mathrm{NcoI}$ and $\mathrm{BamHI}$ and subsequently ligated to yield pNZarcA and pNZarcB. These vectors contain the corresponding genes under the control of

\section{Table 1 Buffers used in this study}

\section{Buffer Composition}

A $100 \mathrm{mM} \mathrm{KPi}, \mathrm{pH} 7.0$

B $\quad 50 \mathrm{mM} \mathrm{KPi}, \mathrm{pH} 7.0$

C $\quad 50 \mathrm{mM} \mathrm{KPi}, \mathrm{pH} 7.0$ with $200 \mathrm{mM} \mathrm{NaCl}$

D $\quad 50 \mathrm{mM} \mathrm{KPi}, \mathrm{pH} 7.0$ with $100 \mathrm{mM} \mathrm{NaCl}$

E $\quad 25 \mathrm{mM} \mathrm{KPi}, \mathrm{pH} 8.0$ with $500 \mathrm{mM} \mathrm{NaCl}$ plus $5 \%$ (v/v) glycerol

F $\quad 50 \mathrm{mM} \mathrm{KPi}, \mathrm{pH} 7.0$ with $200 \mathrm{mM} \mathrm{KCl}$

G $\quad 100 \mathrm{mM} \mathrm{KPi}, \mathrm{pH} 7.0$ with $0.5 \mathrm{mM}$ ornithine

H $\quad 50 \mathrm{mM} \mathrm{NaPi}, \mathrm{pH} 7.0$

I $\quad 100 \mathrm{mM} \mathrm{KPi}, \mathrm{pH} 7.0$ with $250 \mathrm{mM} \mathrm{KCl}$

the nisin-inducible $P_{\text {NIS }}$ promoter ${ }^{45}$ and the genes have a cleavable 6 His-tag at the N-terminus.

The $\operatorname{arcC1}$ and $\operatorname{arcD} 2 \mathrm{PCR}$ inserts were used for ligation-independent cloning as described in ref. ${ }^{46}$. This yielded pNZarcC1 and pNZarcD2 with the genes under the control of the $P_{\text {NIS }}$ promoter and with a cleavable $10 \mathrm{His}$-tag at the N- and Cterminus, respectively. To construct the cysteine-less variant of $\operatorname{arcD2}(\operatorname{arcD} 2 \Delta \mathrm{C})$, two mutations were made, namely C395T and C487T. The $\operatorname{arcD2}$ gene was PCRamplified from pNZarcD2 with uracil-containing primers ( $\operatorname{arcD} 2 \Delta \mathrm{C}-\mathrm{X})$, using PfuX7 DNA polymerase ${ }^{47}$. The two amplified fragments were ligated with USER enzyme (New England Biolabs, Inc.) to create the pNZarcD2 $\Delta \mathrm{C}$ vector.

The $\mathrm{pNZarcA}$, pNZarcB, and pNZarcC1 vectors were transformed into $L$. lactis $\mathrm{NZ9000}{ }^{45}$, while $\mathrm{pNZarcD2}$ and $\mathrm{pNZarcD2} \Delta \mathrm{C}$ were transformed into L. lactis JP9000 $\triangle \operatorname{arcD1D2} 2^{48}$ (Supplementary Table 2). The pRsetB-PercevalHR plasmid was a gift from professor Gary Yellen (Addgene plasmid \#49081, ref. ${ }^{32}$ ) and transformed into E. coli BL21-DE3 (Supplementary Table 2).

Expression of genes. L. lactis cells were grown in rich medium [2\% (w/v) Gistex from Brenntag AG], $65 \mathrm{mM} \mathrm{NaPi}$, pH 7.0, 1\% (w/v) glucose) with $5 \mu \mathrm{g} \mathrm{mL} \mathrm{m}^{-1}$ chloramphenicol at $30^{\circ} \mathrm{C}$ with stirring (200 rpm). The strains for ArcA, ArcB, and ArcCl production were grown as $3 \mathrm{~L}$ cultures in $5 \mathrm{~L}$ flasks and induced at an optical density at $600 \mathrm{~nm}\left(\mathrm{OD}_{600}\right)$ of 0.5 with $0.05 \%(\mathrm{v} / \mathrm{v})$ of culture supernatant from a nisin A-producing strain ${ }^{45}$. In contrast, the strains for ArcD2 and OpuA were grown as $2 \mathrm{~L}$ cultures in a $3 \mathrm{~L}$ bioreactor stirred at $200 \mathrm{rpm}$ with $\mathrm{pH}$ control (kept above pH 6.5 with $4 \mathrm{M} \mathrm{KOH}$ ) and induced at an $\mathrm{OD}_{600}$ of 2.0 with $0.05 \%$ $(\mathrm{v} / \mathrm{v})$ of culture supernatant from a nisin A-producing strain. After induction, all strains were grown for an additional $2 \mathrm{~h}$ before harvesting. Harvesting and washing was done by centrifugation $\left(15 \mathrm{~min}, 6000 \times g, 4^{\circ} \mathrm{C}\right)$ and resuspension of the cells in ice-cold $100 \mathrm{mM} \mathrm{KPi,} \mathrm{pH} 7.0$ (buffer A, Table 1). Finally, cells were centrifuged again and resuspended to an $\mathrm{OD}_{600}$ of 100 in ice-cold $50 \mathrm{mM} \mathrm{KPi}, \mathrm{pH} 7.0$ (buffer B), flash-frozen in liquid nitrogen in aliquots of $50 \mathrm{~mL}$ and stored at $-80^{\circ} \mathrm{C}$.

Preparation of cell lysates and membrane vesicles. The preparation of cell lysate and membrane vesicles was done as follows. After cells were thawed on ice, $100 \mu \mathrm{g} \mathrm{mL}^{-1}$ DNAse and $2 \mathrm{mM} \mathrm{MgSO}_{4}$ were added. Cells were lysed by highpressure disruption (Constant Systems, Ltd.) with two passages at $39 \mathrm{kpsi}$ and $4{ }^{\circ} \mathrm{C}$. After lysis, $5 \mathrm{mM} \mathrm{Na}_{2}$-EDTA (pH 8.0) and $1 \mathrm{mM}$ PMSF (100 mM stock in isopropanol) were added and cell debris was removed by centrifugation $(15 \mathrm{~min}$, $\left.22,000 \times g, 4^{\circ} \mathrm{C}\right)$. Next, the supernatant was centrifuged for $90 \mathrm{~min}$ at $125,000 \times g$ at $4{ }^{\circ} \mathrm{C}$. For ArcA, ArcB, and $\mathrm{ArcC} 1$, the supernatant (containing cell lysate) was flash-frozen in liquid nitrogen in $10 \mathrm{~mL}$ aliquots and stored at $-80^{\circ} \mathrm{C}$. For ArcD2 and OpuA, the pellets (containing membrane vesicles) were resuspended in icecold buffer B [with $20 \%(\mathrm{v} / \mathrm{v})$ glycerol for $\mathrm{OpuA}$ ], to a $10 \mathrm{mg} \mathrm{mL}^{-1}$ protein concentration before flash-freezing ( $2 \mathrm{~mL}$ aliquots) and storage.

E. coli BL21-DE3 pRsetB-PercHR cells were grown in lysogeny broth (LB) with $100 \mu \mathrm{g} \mathrm{mL} \mathrm{m}^{-1}$ ampicillin. In total, $0.5 \mathrm{~L}$ cultures were grown in $5 \mathrm{~L}$ flasks at $30^{\circ} \mathrm{C}$ with shaking $(200 \mathrm{rpm})$ to an $\mathrm{OD}_{600}$ of 0.7 , after which they were cooled to $22^{\circ} \mathrm{C}$, induced with $100 \mu \mathrm{M}$ isopropyl $\beta$-D-1-thiogalactopyranoside (IPTG) and grown for an additional $72 \mathrm{~h}$ before harvesting as described in ref. ${ }^{32}$. Harvesting and washing was done by centrifugation $\left(15 \mathrm{~min}, 6000 \times \mathrm{g}, 4^{\circ} \mathrm{C}\right)$ and resuspension in ice-cold $50 \mathrm{mM} \mathrm{NaPi}$, pH 7.0 with $100 \mathrm{mM} \mathrm{NaCl}$. Finally, cells were centrifuged again and resuspended to an $\mathrm{OD}_{600}$ of 100 in ice-cold $20 \mathrm{mM} \mathrm{NaPi}, \mathrm{pH} 7.0$ with $100 \mathrm{mM} \mathrm{NaCl}$, flash-frozen in liquid nitrogen in $50 \mathrm{~mL}$ aliquots and stored at $-80^{\circ} \mathrm{C}$. Cell lysate was prepared by adding $250 \mu \mathrm{g}$ of DNAse to thawed cells, after which they were lysed by high-pressure disruption in a single passage at $25 \mathrm{kpsi}$ and $4{ }^{\circ} \mathrm{C}$. After lysis, $0.1 \mathrm{mM}$ PMSF was added and cell debris was removed by centrifugation for $60 \mathrm{~min}$ at $145,000 \times g$ at $4^{\circ} \mathrm{C}$. The supernatant (containing cell lysate) was flash-frozen in liquid nitrogen in $15 \mathrm{~mL}$ aliquots and stored at $-80^{\circ} \mathrm{C}$.

Purification of ArcA, ArcB, and ArcC1. All protein purification and handling steps were performed on ice or at $4^{\circ} \mathrm{C}$, except when specified otherwise. $\mathrm{Ni}^{2+}$-Sepharose resin was pre-equilibrated in $50 \mathrm{mM} \mathrm{KPi}$, pH 7.0 , with $200 \mathrm{mM} \mathrm{NaCl}$ (buffer C) with either $10 \mathrm{mM}$ imidazole for ArcA and ArcB or $5 \mathrm{mM}$ imidazole and $10 \%(\mathrm{v} / \mathrm{v})$ glycerol for ArcC1. Cell lysate was thawed on ice, added to the $\mathrm{Ni}^{2+}$-Sepharose 
resin $(0.5 \mathrm{~mL}$ bed volume per $10 \mathrm{mg}$ total protein) and nutated for $1 \mathrm{~h}$. The mixture was poured over a poly-prep column (Bio-Rad Laboratories, Inc.), after which the resin was washed with 20 column volumes of buffer $\mathrm{C}$ with $50 \mathrm{mM}$ imidazole [plus $10 \%(\mathrm{v} / \mathrm{v})$ glycerol for $\mathrm{ArcC} 1]$. Proteins were then eluted with three column volumes of buffer C with $500 \mathrm{mM}$ imidazole [plus 10\% (v/v) glycerol for ArcC1]. The most concentrated fractions were run on a Superdex 200 Increase 10/300 GL size-exclusion column (GE Healthcare) in $50 \mathrm{mM} \mathrm{KPi}$, pH 7.0 with $100 \mathrm{mM} \mathrm{NaCl}$ (buffer D) [plus 10\% (v/v) glycerol for ArcC1]. Protein containing fractions were pooled and concentrated to $4-5 \mathrm{mg} \mathrm{mL}^{-1}$ in a Vivaspin $500(30,000 \mathrm{kDa})$ centrifugal concentrator (Sartorius AG), after which they were aliquoted, flash-frozen in $100 \mu \mathrm{L}$ aliquots and stored at $-80{ }^{\circ} \mathrm{C}$

In addition, $\mathrm{ArcA}, \mathrm{ArcB}$, and $\mathrm{ArcC} 1$ have been purified in $50 \mathrm{mM} \mathrm{NaPi}, \mathrm{pH} 7.0$ instead of $50 \mathrm{mM} \mathrm{KPi} \mathrm{pH} 7.0$ to allow reconstitutions devoid of potassium ions (protocol A6, see below); the system is also fully functional in sodium ion-based buffers.

Purification of PercevalHR. PercevalHR was purified in a manner similar to ArcA, $\mathrm{ArcB}$, and $\mathrm{ArcC} 1$, except that different buffers were used. $\mathrm{Ni}^{2+}-$ Sepharose resin was pre-equilibrated in $25 \mathrm{mM} \mathrm{KPi}$ buffer, $\mathrm{pH} 8.0$ with $500 \mathrm{mM} \mathrm{NaCl}$ with $5 \%(\mathrm{v} / \mathrm{v})$ glycerol (buffer E) plus $10 \mathrm{mM}$ imidazole. The resin was washed with buffer E plus $25 \mathrm{mM}$ imidazole and protein was eluted with buffer E plus $250 \mathrm{mM}$ imidazole. The most concentrated fractions were run on a Superdex 200 Increase 10/300 GL size-exclusion column (GE Healthcare) in $10 \mathrm{mM} \mathrm{NaPi}$, pH 7.4 with $150 \mathrm{mM} \mathrm{NaCl}$ and $5 \%(\mathrm{v} / \mathrm{v})$ glycerol. Protein containing fractions $\left(1-2 \mathrm{mg} \mathrm{mL}^{-1}\right)$ were aliquoted in volumes of $50 \mu \mathrm{L}$, flash-frozen and stored at $-80^{\circ} \mathrm{C}$.

Enzymatic assays for ArcA and ArcB. Activity of ArcA and ArcB was measured with the COLDER assay ${ }^{49}$. In brief, either $2 \mu \mathrm{g} \mathrm{mL}^{-1} \mathrm{ArcA}$, or $0.25 \mu \mathrm{g} \mathrm{mL}^{-1} \mathrm{ArcB}$ was incubated in buffer B at $30^{\circ} \mathrm{C}$ for $3 \mathrm{~min}$, in a total volume of $275 \mu \mathrm{L}$. To start the reaction, varying concentrations of either L-arginine for ArcA $(0-480 \mu \mathrm{M} \mathrm{L}$ arginine), or L-ornithine plus carbamoyl-phosphate for ArcB (0-10 mM Lornithine plus $0-10 \mathrm{mM}$ carbamoyl-phosphate) were added. Two hundred microliters of COLDER solution $(20 \mathrm{mM}$ 2,3-butanedione monoxime, $0.5 \mathrm{mM}$ thiosemicarbazide, $2.25 \mathrm{M}$ phosphoric acid, $4.5 \mathrm{M}$ sulfuric acid and $1.5 \mathrm{mM}$ ammonium iron(III) sulfate) was pipetted into each well of a 96-well flat-bottom transparent polystyrene plate (Greiner Bio-One International $\mathrm{GmbH}$ ), to which $50 \mu \mathrm{L}$ of reaction mixture was added at given time intervals to stop the enzymatic conversion. In addition, a set of calibration samples with citrulline concentrations from 0 to $250 \mu \mathrm{M}$ was added into the wells in the plate. To allow color development, the plate was sealed with thermo resistant tape (Nalge Nunc International) and incubated at $80^{\circ} \mathrm{C}$ for $20 \mathrm{~min}$ in a block heater (Stuart). Afterward, the plate was cooled down to room temperature for $30 \mathrm{~min}$, the condensate was centrifuged $\left(1 \mathrm{~min}, 1000 \times g, 20^{\circ} \mathrm{C}\right.$ ) and the absorbance of the solutions in the wells was measured at $540 \mathrm{~nm}$ in a platereader (BioTek Instruments, Inc.). Enzyme activity (in nmol citrulline $\min ^{-1} \mathrm{mg}$ protein ${ }^{-1}$ ) was determined by the formula:

$$
\mathrm{Act}_{\mathrm{enz}}=\frac{\Delta \mathrm{enz}}{\Delta \mathrm{cal}} * \frac{1}{\mathrm{C}_{\mathrm{enz}} * \mathrm{Vol}_{\mathrm{rmx}}}
$$

where $\Delta \mathrm{enz}$ and $\Delta \mathrm{cal}$ are the slopes of the enzyme and calibration curves, respectively, in $\mathrm{AU} \mathrm{min}-1$ and $\mathrm{AU} \mathrm{nmol}{ }^{-1}$ citrulline; $\mathrm{C}_{\mathrm{enz}}$ is the final concentration of enzyme in $\mathrm{mg} \mathrm{mL}^{-1}$ and $\mathrm{Vol}_{\mathrm{rmx}}$ is the volume of the reaction mixture in $\mathrm{mL}$.

Stability measurements of ArcA and ArcB were performed as described above, with minor adjustments. In brief, ArcA and ArcB were diluted in either buffer B or $300 \mathrm{mM} \mathrm{KPi}, \mathrm{pH} 7.0$, with and without $200 \mathrm{mM}$ glycine betaine, and incubated at $30^{\circ} \mathrm{C}$ for $0,1,3$, and $5 \mathrm{~h}$. To start the reaction, either $150 \mu \mathrm{M}$ arginine (for ArcA) or $5 \mathrm{mM}$ carbamoyl-phosphate plus $5 \mathrm{mM}$ citrulline (for $\mathrm{ArcB}$ ) were added.

Enzymatic assays for ArcC1. The activity of $\mathrm{ArcC} 1$ was measured from changes in ATP/ADP ratio with PercevalHR. In all, $3.3 \mu \mathrm{g} \mathrm{mL}^{-1} \mathrm{ArcCl}$ was incubated in buffer B supplemented with $5 \mathrm{mM}$ of $\mathrm{MgSO}_{4}$ and $10 \mu \mathrm{g} \mathrm{mL}{ }^{-1}$ of purified PercevalHR in 105.250-QS cuvettes (Hellma Analytics) in a FP-8300 spectrofluorometer (Jasco, Inc.). ADP was added in varying concentrations $(0.1-10 \mathrm{mM})$ and the mixture was incubated at $30^{\circ} \mathrm{C}$ for $5 \mathrm{~min}$. To start the reaction, carbamoylphosphate was added in varying concentrations $(0.2-10 \mathrm{mM})$. The fluorescence spectrum of PercevalHR was measured by excitation from $400 \pm 5$ to $510 \pm 5 \mathrm{~nm}$, while the emission was recorded at $550 \pm 5 \mathrm{~nm}$. As the $\mathrm{pH}$ of the reaction mixture changes in time and PercevalHR is sensitive to $\mathrm{pH}$, it was necessary to measure the $\mathrm{pH}$ changes and correct the PercevalHR readout accordingly. In the $\mathrm{pH}$ experiments PercevalHR was substituted with $0.1 \mu \mathrm{M}$ pyranine and the fluorescence spectrum of pyranine was measured by excitation from $380 \pm 5$ to $480 \pm 5 \mathrm{~nm}$, while the emission was recorded at $512 \pm 5 \mathrm{~nm}$. Pyranine was calibrated as described under internal $\mathrm{pH}$ measurements with pyranine (see below)

The PercevalHR signal was calibrated at a sensor concentration of $10 \mu \mathrm{g} \mathrm{mL}^{-1}$ in buffer B with varying $\mathrm{pH}$ values (from 6.6 to 7.6), containing a mixture of ATP and ADP at a total concentration of $5 \mathrm{mM}$ and a total $\mathrm{MgSO}_{4}$ concentration of $5 \mathrm{mM}$. The ATP/ADP ratio was plotted against the ratio of the two excitation peaks at 430 and $500 \mathrm{~nm}$ and were fitted using the Hill equation:

$$
\frac{\mathrm{F} 500 \mathrm{~nm}}{\mathrm{~F} 430 \mathrm{~nm}}=\text { start }+(\text { end }- \text { start }) \frac{\left(\frac{\mathrm{ATP}}{\mathrm{ADP}}\right)^{n}}{k^{n}+\left(\frac{\mathrm{ATP}}{\mathrm{ADP}}\right)^{n}}
$$

where $k$ is the apparent affinity constant; $n$ is the Hill coefficient; start and end refer to the $y$-values at the vertical asymptotes. The Hill coefficient was constrained to 1 When the parameters of datasets recorded at varying $\mathrm{pH}$ values were compared, it was evident that only start and end were affected by $\mathrm{pH}, k$ remained constant. The start and end values were plotted against the $\mathrm{pH}$ and were fitted by using the following logistic equations (Supplementary Fig. 2c):

$$
\text { start }=y_{0}+A \times \mathrm{e}^{R_{0} \times \mathrm{pH}}, \quad \text { end }=y_{0}+A \times \mathrm{e}^{R_{0} \times \mathrm{pH}}
$$

where $y_{0}, A$, and $R_{0}$ are the fit parameters. The resulting equations were incorporated into Eq. (3) to yield a formula in which the ATP/ADP ratio is dependent on the $\mathrm{pH}$ of the solution and the ratio of the excitation peaks at 430 and $500 \mathrm{~nm}$ of PercevalHR

$$
\frac{\mathrm{ATP}}{\mathrm{ADP}}=\frac{4.11 \times\left(\frac{\mathrm{F} 500 \mathrm{~nm}}{\mathrm{~F} 430 \mathrm{~nm}}-\left(-0.021+2 \times 10^{-6} \times \mathrm{e}^{1.76 \times \mathrm{pH}}\right)\right)}{\left(-1.15+3.5 \times 10^{-3} \times \mathrm{e}^{0.96 \times \mathrm{pH}}\right)-\frac{\mathrm{F} 500 \mathrm{~nm}}{\mathrm{~F} 433 \mathrm{~nm}}}
$$

Stability measurements of $\mathrm{ArcCl}$ were performed as described above, with minor adjustments. In brief, ArcC1 was diluted in buffer B or $300 \mathrm{mM} \mathrm{KPi}$, pH 7.0, with and without $200 \mathrm{mM}$ glycine betaine, and incubated at $30^{\circ} \mathrm{C}$ for $0,1,3$ and $5 \mathrm{~h}$. After incubation, $5 \mathrm{mM}$ of ADP, $5 \mathrm{mM}$ of $\mathrm{MgSO}_{4}$ and either PercevalHR or pyranine were added. After $5 \mathrm{~min}$ of incubation at $30^{\circ} \mathrm{C}$, the reaction was started with the addition of $5 \mathrm{mM}$ of carbamoyl-phosphate. For the experiments performed in $300 \mathrm{mM} \mathrm{KPi} \mathrm{pH} 7.0$ a new calibration of both PercevalHR and pyranine was performed, resulting in the following equation:

$$
\frac{\mathrm{ATP}}{\mathrm{ADP}}=\frac{6.59 \times\left(\frac{\mathrm{F} 500 \mathrm{~nm}}{\mathrm{~F} 430 \mathrm{~nm}}-\left(-0.214+8.2 \times 10^{-5} \times \mathrm{e}^{1.29 \times \mathrm{pH}}\right)\right)}{\left(-0.52+6.3 \times 10^{-4} \times \mathrm{e}^{1.15 \times \mathrm{pH}}\right)-\frac{\mathrm{F} 500 \mathrm{~nm}}{\mathrm{~F} 430 \mathrm{~nm}}}
$$

Purification of ArcD2 and OpuA. Membrane vesicles were quickly thawed and diluted to a total protein concentration of $3 \mathrm{mg} \mathrm{mL}^{-1}$ for OpuA and $7 \mathrm{mg} \mathrm{mL}^{-1}$ for ArcD2 in $50 \mathrm{mM} \mathrm{KPi}$, pH 7.0 plus $200 \mathrm{mM} \mathrm{KCl}$ (buffer F) containing 20\% (v/v) glycerol in case of OpuA. $0.5 \%$ (w/v) $n$-dodecyl- $\beta$-D-maltoside (DDM) was added to the vesicles for solubilization and the mixture was nutated for either $30 \mathrm{~min}$ (ArcD2) or $60 \mathrm{~min}(\mathrm{OpuA})$. Unsolubilized material was removed by centrifugation $\left(20 \mathrm{~min}, 270,000 \times g, 4^{\circ} \mathrm{C}\right) . \mathrm{Ni}^{2+}$-Sepharose resin $\left(0.5 \mathrm{~mL}\right.$ of $\mathrm{Ni}^{2+}$-Sepharose resin per $20 \mathrm{mg}$ total protein for OpuA or $0.25 \mathrm{~mL}$ of $\mathrm{Ni}^{2+}$-Sepharose resin per $10 \mathrm{mg}$ total protein for ArcD2) was pre-equilibrated in buffer F with $10 \mathrm{mM}$ imidazole plus $0.03 \%(\mathrm{w} / \mathrm{v}) \mathrm{DDM}$. The supernatant was diluted $1.6 \times$ fold $(\mathrm{ArcD} 2)$ or $2.5 \times$ fold (OpuA) to reduce the DDM concentration and then added to the $\mathrm{Ni}^{2+}$-Sepharose column material and nutated for $1 \mathrm{~h}$ at $4^{\circ} \mathrm{C}$. The mixture was poured into a polyprep column, after which the resin was washed with 20 column volumes of buffer F containing $50 \mathrm{mM}$ imidazole plus $0.02 \%(\mathrm{w} / \mathrm{v}) \mathrm{DDM}$ and $20 \%(\mathrm{v} / \mathrm{v})$ glycerol in case of OpuA. Proteins were eluted in 3 column volumes of buffer $F$ with $500 \mathrm{mM}$ imidazole plus $0.02 \%(\mathrm{w} / \mathrm{v}) \mathrm{DDM}$ and $20 \%(\mathrm{v} / \mathrm{v})$ glycerol in case of OpuA.

Light scattering for oligomeric state determination. $\mathrm{Ni}^{2+}-\mathrm{Sepharose} / \mathrm{size}-$ exclusion chromatography-purified fractions of ArcA, ArcB, ArcC, and ArcD2 were analyzed on a second Superdex 200 Increase 10/300 GL size-exclusion column (GE Healthcare) in buffer D [with $0.02 \%$ (w/v) DDM for ArcD2], which was coupled to a multi-angle light scattering system with detectors for absorbance at $280 \mathrm{~nm}$ (Agilent Technologies, Inc.), static light scattering (Wyatt Technology Corporation) and differential refractive index (Wyatt Technology Corporation). Data analysis was performed with the ASTRA software package (Wyatt Technology Corporation), using a value for the refractive index increment $(\mathrm{d} n / \mathrm{d} c)_{\text {protein }}$ of $0.180 \mathrm{~mL} \mathrm{mg}^{-1}$ and $(\mathrm{d} n / \mathrm{d} c)_{\text {detergent }}$ of $0.143 \mathrm{~mL} \mathrm{mg}^{-150}$.

Co-reconstitution of ArcD2 and OpuA. Synthetic lipids were mixed from chloroform stocks in the ratio of either $50 \mathrm{~mol} \%$ DOPE, $12 \mathrm{~mol} \%$ DOPC, and $38 \mathrm{~mol} \%$ DOPG or $50 \mathrm{~mol} \%$ DOPE, $37 \mathrm{~mol} \%$ DOPC, and $13 \mathrm{~mol} \%$ DOPG. Lipids were dried in a rotary vacuum setup (Büchi Labortechnik AG), dissolved in diethyl ether, dried again and rehydrated in buffer $B$ to a final lipid concentration of $20 \mathrm{mg} \mathrm{mL}^{-1}$. Dissolved lipids, cooled with ice water, were sonicated with a tip sonicator (Sonics and Materials, Inc.) (15 s on, $45 \mathrm{~s}$ off, $70 \%$ amplitude, 16 cycles) frozen-thawed three times, alternating between liquid nitrogen and (a water bath at) room temperature, and extruded 13 times through a $400 \mathrm{~nm}$ pore size polycarbonate filter (Avestin Europe $\mathrm{GmbH}$ ) to obtain liposomes. Using an established protocol $^{41}, \mathrm{ArcD} 2$ and OpuA were co-reconstituted in preformed liposomes at a protein to lipid ratio of 1:2:400 (w/w), respectively. The liposomes were first diluted five times to a final concentration of $4 \mathrm{mg} \mathrm{mL}^{-1}$ in buffer B with $25 \%(\mathrm{v} / \mathrm{v})$ glycerol [final concentration $20 \%(\mathrm{v} / \mathrm{v})$ ] and then destabilized by a stepwise titration with $10 \%(\mathrm{v} / \mathrm{v})$ Triton X-100, until the membrane was saturated with detergent $\left(R_{\text {sat; }}\right.$ ref. ${ }^{51}$ ), after which the membrane proteins were added. The purified proteins and destabilized liposomes were mixed for $15 \mathrm{~min}$ at $4{ }^{\circ} \mathrm{C}$, after which detergent was removed by adding SM2 biobeads ( $600 \mathrm{mg}$ per $20 \mathrm{mg}$ of lipids) in three equal aliquots with $15 \mathrm{~min}$ incubation in between each addition. After the third addition, 
Table 2 Average number of molecules per vesicle

\section{Compound}

Ornithine

ADP

$\mathrm{Mg}^{2+}$

Pyranine

PercevalHR

Phosphate

$\mathrm{K}^{+}$

$\mathrm{Na}^{+}$

$\mathrm{Cl}^{-}$

of 3 (without GB uptake) $3.75 / 1.25 \mathrm{mM}$

ATP/ADP ratio of 2 (with GB uptake)

Glycine betaine (imported)

$0.5 \mathrm{mM}$
$5 \mathrm{mM}$
$5 \mathrm{mM}$
$100 \mu \mathrm{M}$
$2.9 \mu \mathrm{M}$
$50 \mathrm{mM}$
$50 \mathrm{mM}$
$25 / 40 \mathrm{mM}$
$25 / 40 \mathrm{mM}$
$3.75 / 1.25 \mathrm{mM}$
$3.33 / 1.67 \mathrm{mM}$
$50 \mathrm{mM}$

Internal concentration Molecules per vesicle ( $84 \mathrm{~nm}$ radius)

740
7400
7400
150
4
73,700
73,700
$36,800 / 59,000$
$36,800 / 59,000$
$5500 / 1800$
$4900 / 2500$
73,700

Molecules per vesicle (225 $\mathrm{nm}$ radius)

14,500

144,600

144,600

2900

83

$1,446,200$

$1,446,200$

$723,100 / 1,157,000$

$723,100 / 1,157,000$

$108,500 / 36,200$

$96,400 / 48,200$

$1,446,200$ the mixture was incubated overnight, which was followed by one additional addition (200 mg per $20 \mathrm{mg}$ of lipids) of SM2 biobeads and incubation for $1 \mathrm{~h}$. Finally, the proteoliposomes were collected by centrifugation $(2 \mathrm{~h}$ for $38 \%(\mathrm{w} / \mathrm{w})$ DOPG lipids or $4 \mathrm{~h}$ for $13 \%$ (w/w) DOPG lipids, $125,000 \times g, 4{ }^{\circ} \mathrm{C}$ ) and resuspended in $200 \mu \mathrm{L}$ per $20 \mathrm{mg}$ of lipids, yielding a final lipid concentration of $100 \mathrm{mg}$ $\mathrm{mL}^{-1}$. For the ${ }^{14} \mathrm{C}$-arginine transport assay (see transport assays), reconstitution was done similarly as above, except that $\mathrm{ArcD} 2$ was reconstituted at a protein to lipid ratio of 2:400 (w/w). In addition, the proteoliposomes were diluted in buffer $\mathrm{B}$ without glycerol and centrifugation was done for $30 \mathrm{~min}, 325,000 \times \mathrm{g}, 4^{\circ} \mathrm{C}$.

Vesicles with a radius of $226 \mathrm{~nm}$ have $1.8 \times 10^{6}$ lipids per vesicle. Hence, a protein-to-lipid ratio of 400:1 (w/w) or $2.9 \times 10^{4}(\mathrm{~mol} / \mathrm{mol})$ for ArcD2 and 200:1 $(\mathrm{w} / \mathrm{w})$ or $5.7 \times 10^{4}(\mathrm{~mol} / \mathrm{mol})$ for OpuA yield 62 molecules of ArcD2 and 31 molecules of OpuA per vesicle.

Encapsulation of the arginine breakdown pathway. Protocol A1: The ArcD2and OpuA-containing vesicles used for most studies were composed of $50 \mathrm{~mol} \%$ DOPE, $12 \mathrm{~mol} \%$ DOPC plus $38 \mathrm{~mol} \%$ DOPG. The proteoliposomes $(66 \mu \mathrm{L}, 6.6 \mathrm{mg}$ of lipid) containing ArcD2 and OpuA were mixed in buffer B with $1 \mu \mathrm{M}$ ArcA, $2 \mu \mathrm{M}$ ArcB, $5 \mu \mathrm{M}$ ArcC1, $5 \mathrm{mM}$ ADP, $5 \mathrm{mM} \mathrm{MgSO}_{4}, 0.5 \mathrm{mM}$ ornithine and optionally $1.6-2.9 \mu \mathrm{M}$ PercevalHR or $100 \mu \mathrm{M}$ pyranine in a total volume of $200 \mu \mathrm{L}$; the final liposome concentration is $33 \mathrm{mg}$ of lipid $\mathrm{mL}^{-1}$. This yields a final buffer of $50 \mathrm{mM} \mathrm{KPi}$ pH 7.0 plus $25 \mathrm{mM} \mathrm{NaCl}$ (carried over with the purified ArcA, ArcB, and ArcC1) or $40 \mathrm{mM} \mathrm{NaCl}$ when PercevalHR is also included (see Table 2). The enzymes, metabolites and dyes were encapsulated by five freeze-thaw cycles in a $0.5 \mathrm{ml}$ Eppendorf tube, alternating between liquid nitrogen and a $10^{\circ} \mathrm{C}$ water bath, with vortexing of the tube before freezing. Next, the vesicles were extruded 13 times through a $400 \mathrm{~nm}$ pore size polycarbonate filter; the extruder was pre-washed in buffer A with $0.5 \mathrm{mM}$ ornithine (buffer $\mathrm{G}$ ). This procedure homogenizes the vesicles further and makes it likely that necessary components are present in all layers and compartments. The vesicles with encapsulated pyranine were then separated from free pyranine by running them over a $22 \mathrm{~cm}$ long Sephadex G-75 (Sigma) column in buffer $\mathrm{G}$ at $4{ }^{\circ} \mathrm{C}$. To remove the residual external compounds, the vesicles were diluted to $6 \mathrm{~mL}$ in buffer $\mathrm{G}$, collected by centrifugation $(20 \mathrm{~min}$, $\left.325,000 \times g, 4^{\circ} \mathrm{C}\right)$ and washed with buffer $\mathrm{G}(6 \mathrm{~mL})$, after which the vesicles were centrifuged and resuspended in $40 \mu \mathrm{L}$ per $6.6 \mathrm{mg}$ of lipid, yielding a final concentration of $165 \mathrm{mg}$ of lipid $\mathrm{mL}^{-1}$. Vesicles were kept on ice before subsequent measurements. Importantly, the ratio of the components inside the vesicles is very similar to the ratio in solution prior to encapsulation (Supplementary Fig. 6).

Protocol A2: Like protocol A1 except that the proteoliposomes were mixed with internal components in $60 \mathrm{mM} \mathrm{KCl}$, yielding a final buffer of $15 \mathrm{mM} \mathrm{KPi} \mathrm{pH} 7.0$ plus $25 \mathrm{mM} \mathrm{NaCl}$ and $40 \mathrm{mM} \mathrm{KCl}$.

Protocol A3: Like protocol A1 except that the vesicles were loaded with $15 \mathrm{mM}$ ADP plus equimolar concentrations of $\mathrm{MgSO}_{4}$.

Protocol A4: Like protocol A1 except that the vesicles were extruded through a $200 \mathrm{~nm}$ pore size polycarbonate filter.

Protocol A5: Like protocol A1 except that the vesicles were loaded with $10 \mathrm{mM}$ ATP, $10 \mathrm{mM} \mathrm{MgSO}_{4}, 24 \mathrm{mM}$ creatine-phosphate, and $2.4 \mathrm{mg} \mathrm{mL}^{-1}$ creatine kinase in buffer $\mathrm{B}^{40}$.

Protocol A6: Like protocol A1 except that the proteoliposomes containing ArcD2 and OpuA were first diluted in $6 \mathrm{ml}$ of $50 \mathrm{mM} \mathrm{NaPi}, \mathrm{pH} 7.0$ (buffer $\mathrm{H}$ ), collected by centrifugation $\left(20 \mathrm{~min}, 325,000 \times g, 4{ }^{\circ} \mathrm{C}\right)$ and resuspended in $66 \mu \mathrm{l}$ of buffer $\mathrm{H}$. They were then mixed in buffer $\mathrm{H}$ with the components mentioned above and the ArcA, ArcB, and ArcC1 purified in $50 \mathrm{mM} \mathrm{NaPi}$ instead of $50 \mathrm{mM} \mathrm{KPi}$. In addition, the extruder was pre-washed and vesicles were resuspended in buffer $\mathrm{H}$ with L-ornithine. This encapsulation yields only sodium and no potassium ions inside the vesicles.

Protocol A7: Like protocol A1 except that the vesicles consisted of $50 \mathrm{~mol} \%$ DOPE, $37 \mathrm{~mol} \%$ DOPC plus $13 \mathrm{~mol} \%$ DOPG.
Cryo-EM analysis of vesicles. The vesicles with encapsulated enzymes, metabolites (and sensors) were vitrified and imaging was done on a FEI Tecnai T20, $200 \mathrm{keV}$; Cryo-stage Gatan model 626. Samples were prepared under isosmotic conditions and images were recorded under low-dose conditions ${ }^{52}$. Approximate diameters of the vesicles were measured in ImageJ. The diameters were converted to internal volume by assuming spherical vesicles, multiplication by abundance and re-normalization.

Transport assays. Protocol B1: The vesicles with encapsulated enzymes and metabolites were diluted to a final concentration of $1.67 \mathrm{mg} \mathrm{mL}^{-1}$ in buffer A with $250 \mathrm{mM} \mathrm{KCl}$ (buffer I). Glycine betaine was added at a final concentration of $18 \mu \mathrm{M}$, of which $2 \%(\mathrm{~mol} / \mathrm{mol})$ was ${ }^{14} \mathrm{C}$-radiolabeled. The mixture was incubated for $30 \mathrm{~min}$ at $30^{\circ} \mathrm{C}$. The internal ATP production was then started by addition of $20 \mathrm{mM}$ arginine and samples of $50 \mu \mathrm{L}$ were taken at given time intervals. Samples were diluted in $2 \mathrm{~mL}$ of ice-cold buffer I and filtered over $0.45 \mu \mathrm{m}$ pore size cellulose nitrate filters to stop the transport assay. The filter was then washed with another $2 \mathrm{~mL}$ of buffer I. Radioactivity on the filter was quantified by liquid scintillation counting using Ultima Gold MV scintillation fluid (PerkinElmer) and a Tri-Carb 2800TR scintillation counter (PerkinElmer). The pore size of the filters is larger than the diameter of the vesicles, but the filters retain more than $99 \%$ of the vesicles and allow for rapid filtration ${ }^{41}$.

Protocol B2: The transport of ${ }^{14} \mathrm{C}$-arginine was measured similarly, except that proteoliposomes ( $66 \mu \mathrm{L}, 6.6 \mathrm{mg}$ of lipid) with only ArcD2 in the membrane and L-ornithine or L-citrulline $(100 \mu \mathrm{M}, 1 \mathrm{mM}$, or $10 \mathrm{mM})$ in buffer B in the vesicle lumen, were used (encapsulation was done by five freeze-thaw cycles in a total volume of $200 \mu \mathrm{L}$ ). The proteoliposomes were first extruded 13 times through a $400 \mathrm{~nm}$ pore size polycarbonate filter, then 13 times through a $200 \mathrm{~nm}$ filter and diluted to $6 \mathrm{~mL}$ in buffer $\mathrm{B}$ with or without the same concentration of L-ornithine or L-citrulline as on the inside. Proteoliposomes were collected by centrifugation $\left(20 \mathrm{~min}, 225,000 \times g, 4^{\circ} \mathrm{C}\right)$ and either washed with buffer B $(6 \mathrm{~mL})$, centrifuged again and resuspended in $30 \mu \mathrm{L}$ buffer B per $6.6 \mathrm{mg}$ of lipid, or directly resuspended in buffer $\mathrm{B}$ with the appropriate concentration of $\mathrm{L}$ ornithine or L-citrulline, yielding a final concentration of $220 \mathrm{mg}$ of lipid $\mathrm{mL}^{-1}$. For the transport assay, proteoliposomes were diluted to a final concentration of $2.2 \mathrm{mg}$ of lipid $\mathrm{mL}^{-1}$, in buffer B with $10 \mu \mathrm{M}$ arginine, of which $10 \%(\mathrm{~mol} / \mathrm{mol})$ was ${ }^{14} \mathrm{C}$-radiolabeled, and $100 \mu \mathrm{L}$ samples were taken at given time intervals. To impose a membrane potential, proteoliposomes in buffer $\mathrm{B}$, were diluted 100fold in $50 \mathrm{mM} \mathrm{NaPi}(\Delta \Psi=-120 \mathrm{mV})$, pH $7.0 ; 48.15 \mathrm{mM} \mathrm{NaPi}$ plus $1.85 \mathrm{mM}$ $\mathrm{KPi}, \mathrm{pH} 7.0(\Delta \Psi=-80 \mathrm{mV})$; or $39.6 \mathrm{mM}$ NaPi plus $10.4 \mathrm{mM} \mathrm{KPi,} \mathrm{pH} 7.0$ $(\Delta \Psi=-40 \mathrm{mV})$, each supplemented with $1 \mu \mathrm{M}$ of the potassium ionophore valinomycin.

Internal ATP:ADP ratio measurements with PercevalHR. Calibration: Purified PercevalHR and nucleotides (ATP and ADP) were encapsulated in liposomes. The encapsulation mixture contained liposomes at $7.5 \mathrm{mg}$ of lipids $\mathrm{mL}^{-1}, 1.6-2.9 \mu \mathrm{M}$ PercevalHR, $5 \mathrm{mM}$ of nucleotides in varying ratios, and $5 \mathrm{mM} \mathrm{MgSO}_{4}$ in buffer $\mathrm{B}$. The samples were frozen-thawed five times, extruded 13 times through a $400 \mathrm{~nm}$ pore size polycarbonate filter, centrifuged twice $\left(20 \mathrm{~min}, 225,000 \times \mathrm{g}, 4{ }^{\circ} \mathrm{C}\right)$ and finally resuspended in buffer B to a concentration of $167 \mathrm{mg} \mathrm{mL}^{-1}$. The liposomes were diluted in buffer I with $10 \mu \mathrm{M}$ carbonyl cyanide-4-(trifluoromethoxy) phenylhydrazone (FCCP) to a final concentration of $3.34 \mathrm{mg}$ lipids $\mathrm{mL}^{-1}$ in 105.250QS cuvettes (Hellma Analytics) in a FP-8300 spectrofluorometer (Jasco, Inc.) and incubated for $3 \mathrm{~min}$ at $30^{\circ} \mathrm{C}$. The fluorescence spectrum of PercevalHR was measured by excitation from $400 \pm 5$ to $510 \pm 5 \mathrm{~nm}$, while the emission was recorded at $550 \pm 5 \mathrm{~nm}$. The encapsulated ATP/ADP ratio was plotted against the ratio of the peaks at 500 and $430 \mathrm{~nm}$. Equation (3) was re-written with $n=1$, to 
obtain the following equation:

$$
\frac{\mathrm{ATP}}{\mathrm{ADP}}=\frac{k *\left(\frac{\mathrm{F} 500 \mathrm{~nm}}{\mathrm{~F} 430 \mathrm{~nm}}-\text { start }\right)}{\text { end }-\frac{\mathrm{F} 500 \mathrm{~nm}}{\mathrm{~F} 430 \mathrm{~nm}}}
$$

By fitting Eq. (7) to the data points (Supplementary Fig. 2d) the following values were obtained: $k=3.02$, start $=0.46$, end $=1.30$

Protocol B3: The vesicles with encapsulated enzymes, metabolites and PercevalHR were diluted in buffer I with $10 \mu \mathrm{M}$ FCCP to a final concentration of $3.34 \mathrm{mg}$ of lipid $\mathrm{mL}^{-1}$ in 105.250-QS cuvettes (Hellma Analytics) in a FP-8300 spectrofluorometer (Jasco, Inc.) and incubated for $30 \mathrm{~min}$ at $30^{\circ} \mathrm{C}$. To start ATP production, $5 \mathrm{mM}$ arginine was added, and after $30 \mathrm{~min}$ of incubation glycine betaine $(0,180 \mu \mathrm{M}$ or $3.6 \mathrm{mM})$ was added. The fluorescence spectrum of PercevalHR was measured continuously, as described above. The ATP/ADP ratio was obtained from the ratio of the peaks at 500 and $430 \mathrm{~nm}$, using Eq. (4). Representative traces are shown in the figure panels, but replicate experiments have been performed multiple times $(n)$; $n$ values are given in the figure legends.

Internal pH measurements with pyranine. Calibration: $100 \mu \mathrm{M}$ pyranine was encapsulated in liposomes at varying pH between 6.0 and 8.0 in $50 \mathrm{mM} \mathrm{KPi}$. The samples were frozen-thawed five times, extruded 13 times through a $400 \mathrm{~nm}$ pore size polycarbonate filter, and run over a $22 \mathrm{~cm}$ long Sephadex G-75 (Sigma) column. The vesicles were collected by centrifugation $\left(20 \mathrm{~min}, 325,000 \times g, 4^{\circ} \mathrm{C}\right)$, washed once, centrifuged and resuspended to a concentration of $167 \mathrm{mg}$ of lipid $\mathrm{mL}^{-1}$. The liposomes were diluted in $50 \mathrm{mM} \mathrm{KPi}$ at varying $\mathrm{pH}$ to a final concentration of $3.34 \mathrm{mg}$ lipids $\mathrm{mL}^{-1}$ in 105.250 -QS cuvettes (Hellma Analytics) in a FP-8300 spectrofluorometer (Jasco, Inc.) and incubated for $3 \mathrm{~min}$ at $30^{\circ} \mathrm{C}$. The fluorescence spectrum of pyranine was measured by excitation from $380 \pm 5$ to 480 $\pm 5 \mathrm{~nm}$, while the emission was recorded at $512 \pm 5 \mathrm{~nm}$. The fluorescence spectrum of $0.1 \mu \mathrm{M}$ pyranine in solution at varying $\mathrm{pH}$ between 6.0 and 9.0 in $50 \mathrm{mM} \mathrm{KPi}$ was also measured. The data points from encapsulated pyranine in unshocked vesicles overlapped perfectly with the in-solution data, therefore the $\mathrm{pH}$ in solution was plotted against the ratio of the peaks at 450 and $405 \mathrm{~nm}$ and fitted using the following logistic function:

$$
y=\frac{L}{1+\mathrm{e}^{-k \times\left(x-x_{0}\right)}}
$$

where $L$ is the curve's maximum value; $k$ is the logistic growth rate and $x_{0}$ is the $x$ value of the sigmoid's midpoint. Equation (8) was re-written with the following parameters: $x=\mathrm{pH}$ and $y=\mathrm{F} 450 \mathrm{~nm} / \mathrm{F} 405 \mathrm{~nm}$ to obtain the following equation:

$$
\mathrm{pH}=\frac{\ln \left(L \times \frac{\mathrm{F} 405 \mathrm{~nm}}{\mathrm{~F} 450 \mathrm{~nm}}-1\right)}{-k}+x_{0}
$$

By fitting Eq. (8) to the data points in $50 \mathrm{mM} \mathrm{KPi} \mathrm{(Supplementary} \mathrm{Fig.} \mathrm{4b),} \mathrm{the}$ following values were obtained: $L=3.60, k=2.38$, and $x_{0}=7.84$.

When vesicles are exposed to an osmotic upshift by the addition of $250 \mathrm{mM}$ $\mathrm{KCl}$, the internal KPi concentration increases to $\sim 300 \mathrm{mM}$. The high salt concentration shifts the calibration of pyranine, and therefore additional calibration curves were made with pyranine in $300 \mathrm{mM} \mathrm{KPi}$ at $\mathrm{pH}$ values ranging from 6.0 and 9.0. This data was fitted to Eq. (8) (Supplementary Fig. 4b), as above, to obtain the following values: $L=3.70, k=2.21$, and $x_{0}=7.57$. The calibration is also shifted when the vesicles were encapsulated with $15 \mathrm{mM} \mathrm{Mg-ADP}$ instead of $5 \mathrm{mM}$ Mg-ADP (see protocol A3). Therefore, we also made calibration curves with pyranine in $300 \mathrm{mM} \mathrm{KPi}$ plus $15 \mathrm{mM} \mathrm{Mg}$-ADP at $\mathrm{pH}$ values ranging from 6.0 to 7.5 (with $15 \mathrm{Mg}$-ADP and $300 \mathrm{mM} \mathrm{KPi}$ the salts precipitated above $\mathrm{pH}$ 7.5). This data was fitted to Eq. (8) (Supplementary Fig. 4c) to obtain the following values: $L=3.22, k=2.16$, and $x_{0}=7.56$.

Protocol B4: The vesicles with encapsulated enzymes, metabolites and pyranine were diluted in buffer I to a final concentration of $3.34 \mathrm{mg}$ lipids $\mathrm{mL}^{-1}$ in 105.250QS cuvettes (Hellma Analytics) in a FP-8300 spectrofluorometer (Jasco, Inc.) and incubated for $30 \mathrm{~min}$ at $30^{\circ} \mathrm{C}$. To start the ATP production, 5 or $20 \mathrm{mM}$ arginine was added and after $30 \mathrm{~min}$ of incubation, glycine betaine was added at a concentration of 0 or $180 \mu \mathrm{M}$. The fluorescence spectrum of pyranine was measured as indicated above, and the internal $\mathrm{pH}$ was obtained from Eq. (9). Representative traces are shown in the figure panels, but replicate experiments have been performed multiple times $(n) ; n$ values are given in the figure legends.

External pH measurements with pyranine. Calibration: The fluorescence spectrum of pyranine was measured by excitation from $380 \pm 5$ to $480 \pm 5 \mathrm{~nm}$, while the emission was recorded at $512 \pm 5 \mathrm{~nm}$. The fluorescence spectrum of $0.1 \mu \mathrm{M}$ pyranine in solution at varying $\mathrm{pH}$ between 6.0 and 8.5 in $10 \mathrm{mM} \mathrm{KPi}$ plus $355 \mathrm{mM}$ $\mathrm{KCl}$ was measured. The $\mathrm{pH}$ in solution was plotted against the ratio of the peaks at 450 and $405 \mathrm{~nm}$ and fitted using Eq. (8) (Supplementary Fig. 4d), from which the following values were obtained: $L=3.27, k=2.23$ and $x_{0}=7.48$.

Protocol B5: The vesicles with encapsulated enzymes and metabolites were diluted in $10 \mathrm{mM} \mathrm{KPi} \mathrm{pH} 7.0$ plus $355 \mathrm{mM} \mathrm{KCl}$ to a final concentration of 3.34 $\mathrm{mg}$ of lipids $\mathrm{mL}^{-1}$ in 105.250-QS cuvettes (Hellma Analytics) in a FP-8300 spectrofluorometer (Jasco, Inc.) and incubated for $30 \mathrm{~min}$ at $30^{\circ} \mathrm{C}$. To start the ATP production, $5 \mathrm{mM}$ arginine was added. The fluorescence spectrum of pyranine was measured as indicated above, and the internal $\mathrm{pH}$ was obtained from Eq. (9). Representative traces are shown in the figure panels, but replicate experiments have been performed multiple times $(n) ; n$ values are given in the figure legends.

Amino acid and ammonia analysis. Protocol B6: The vesicles with encapsulated enzymes and metabolites were diluted in buffer I, with or without glycine betaine, to a final concentration of $3.34 \mathrm{mg}$ of lipid $\mathrm{mL}^{-1}$ and incubated for $30 \mathrm{~min}$ at $30^{\circ} \mathrm{C}$. The assay was started by addition of $5 \mathrm{mM}$ arginine and samples of $75 \mu \mathrm{L}$ were taken at regular time intervals. Vesicles were removed from the samples by centrifugation $\left(20 \mathrm{~min}, 225,000 \times g, 4^{\circ} \mathrm{C}\right)$ to stop the conversion of external amino acids. Subsequently, $50 \mu \mathrm{L}$ of supernatant was mixed with $87.5 \mu \mathrm{L}$ of $1 \mathrm{M}$ boric acid, pH 9.0 (adjusted with $4 \mathrm{M} \mathrm{KOH}$ ) and kept on ice before derivatization. In total, $37.5 \mu \mathrm{L}$ of $99.8 \%$ methanol and $1.5 \mu \mathrm{L}$ of $42 \mathrm{mM}$ diethyl ethoxymethylenemalonate (DEEMM) were added to the samples for derivatization, after which the samples were incubated for $30 \mathrm{~min}$ in a sonication bath at room temperature, followed by $2 \mathrm{~h}$ of incubation in a heat block at $70^{\circ} \mathrm{C}$. The protocol for reverse-phase HPLC was adapted from ref. ${ }^{53}$. Amino acid samples were analyzed on a Shimadzu prominence HPLC system, containing a DGU-20A5R degassing unit, a LC-30AD solvent delivery unit, a SIL-30AC autosampler, a CTO-20AC column oven, and an SPD-M20A UV-VIS/Photodiode Array detector. A Shimadzu XR-ODS $3 \times 75 \mathrm{~mm}$ C18 column was used to run the binary gradient with a flow rate of $0.9 \mathrm{~mL} \mathrm{~min}^{-1}$ and an injection volume of $5 \mu \mathrm{L}$. Eluent A was $25 \mathrm{mM}$ acetate, $\mathrm{pH} 5.8$, supplemented with $0.02 \%(\mathrm{w} / \mathrm{v}) \mathrm{Na}$-azide. Eluent B was an $8: 2(\mathrm{v} / \mathrm{v})$ mixture of acetonitrile and methanol. The gradient was as follows (all percentages are volumebased): start was at $94 \%$ Eluent $\mathrm{A}$ and $6 \% \mathrm{~B} ; 87 \% \mathrm{~A}$ and $13 \% \mathrm{~B}$ at $2 \mathrm{~min} ; 83 \% \mathrm{~A}$ and $17 \% \mathrm{~B}$ at $10 \mathrm{~min} ; 71 \% \mathrm{~A}$ and $29 \% \mathrm{~B}$ at $11 \mathrm{~min} ; 67 \% \mathrm{~A}$ and $33 \% \mathrm{~B}$ at $16 \mathrm{~min} ; 40 \% \mathrm{~A}$ and $60 \% \mathrm{~B}$ at $16.1-18 \mathrm{~min} ; 94 \% \mathrm{~A}$ and $6 \% \mathrm{~B}$ at $18.1 \mathrm{~min}$ toward the end of the protocol at $20 \mathrm{~min}$. The compounds were identified based on retention times and quantified using the external standard method (Supplementary Fig. 7).

Membrane permeability with stopped-flow fluorescence. Principle of the method: To determine the permeability of solutes through the vesicle membrane, two independent and complementary fluorescence-based kinetic assays were used as described in M. Gabba et al. (manuscript in preparation). The first assay reports volume changes of vesicles by means of calcein self-quenching fluorescence ${ }^{31}$. The second assay monitors the $\mathrm{pH}$ variation in the vesicle lumen using the ratio-metric fluorophore pyranine $e^{54}$. Both assays exploit the out-of-equilibrium relaxation kinetics of the vesicles after the increase of the external osmotic pressure (osmotic upshift), i.e., the addition of a solute to the vesicle solution. After the osmotic upshift, the thermodynamic equilibrium is re-established by (i) water efflux (to reequilibrate the chemical potential of water) and/or (ii) solute influx (to dissipate the solute concentration gradient). The contribution of the two fluxes to the recovery kinetics depends on the relative permeability of water and the solute as described in M. Gabba et al. (manuscript in preparation).

Osmolyte solutions: The $1 \mathrm{M}$ stock solutions of Na-acetate, $\mathrm{NH}_{4} \mathrm{Cl}$, and $\mathrm{NH}_{4}$ acetate were prepared by dissolving the salts into $100 \mathrm{mM} \mathrm{KPi}$ buffer; the $\mathrm{pH}$ was adjusted to 7.0 using $4 \mathrm{M} \mathrm{NaOH}$. An empirical linear relation between concentration and osmolality for each solution was determined as described in $\mathrm{M}$. Gabba et al. (manuscript in preparation). The stock solutions were then diluted to an osmolality of ca. 300 mosmol kg-1 by mixing with the liposome solution (yielding $95 \mathrm{mM} \mathrm{Na}$-acetate, $110 \mathrm{mM} \mathrm{NH}_{4} \mathrm{Cl}$, and $110 \mathrm{mM} \mathrm{NH}_{4}$-acetate).

Liposome preparation: Liposomes were prepared as described under internal $\mathrm{pH}$ measurements with pyranine (see above), with minor adjustments. Calcein was added to the vesicle solution ( $2 \mathrm{mg}$ of lipid in buffer $\mathrm{A}$ in a total volume of $1 \mathrm{~mL}$ ) at a self-quenching concentration of $10 \mathrm{mM}$ and enclosed by three cycles of freezing and thawing, alternating between liquid nitrogen and a $40{ }^{\circ} \mathrm{C}$ water bath. Pyranine ( $300 \mu \mathrm{M}$ pyranine, final concentration) was encapsulated similarly. Next, the liposomes were extruded 13 times through a $200 \mathrm{~nm}$ pore size polycarbonate filter and run over a $22 \mathrm{~cm}$ long Sephadex G-75 (Sigma) column in buffer A. Vesicles were collected and diluted to a total volume of $12 \mathrm{~mL}$ in buffer A. Empty liposomes for blank correction were prepared using the same procedure without addition of calcein or pyranine.

Stopped-flow fluorescence measurements: The permeability of the liposomes for $\mathrm{KPi}, \mathrm{KCl}, \mathrm{Na}$-acetate, $\mathrm{NH}_{4} \mathrm{Cl}$, and $\mathrm{NH}_{4}$-acetate was assessed by monitoring the quenching of the fluorescence of calcein and by determining the changes in the internal $\mathrm{pH}$ using pyranine as a probe. A stopped-flow apparatus (SX20, Applied Photophysics Lim., Leatherhead, Surrey, UK) was used to measure fluorescence intensity kinetics upon imposition of an osmotic upshift to the liposomes filled with calcein or pyranine. The osmolyte (ca. $300 \mathrm{mosmol} \mathrm{kg}-1$ after mixing) and the liposome solutions (pre-equilibrated with $250 \mathrm{mM} \mathrm{KCl}$ ) were loaded each in two distinct syringes, forced through the mixer (1:1 mixing ratio and $2 \mathrm{~ms}$ dead time) and into the optical cell $(20 \mu \mathrm{l}$ volume and $2 \mathrm{~mm}$ path length). The temperature was set at $20^{\circ} \mathrm{C}$ using a water bath. The white light emitted by a Xenon arc lamp $(150 \mathrm{~W})$ was passed through a high precision monochromator and directed to the optical cell via an optical fiber. The band pass of the monochromator was optimized and set to $0.5 \mathrm{~nm}$ (for calcein) or $1.4 \mathrm{~nm}$ (for pyranine) to prevent fluorophore photobleaching during the experiment. The fluorophores were excited at $495 \mathrm{~nm}$ (for calcein) or at both 405 and $453 \mathrm{~nm}$ (for pyranine). The emitted light, collected at $90^{\circ}$, was filtered by a 
Schott long-pass filter (cut-off wavelength at $515 \mathrm{~nm}$ ) and detected by a photomultiplier tube (Hamamatsu R6095) with $10 \mu$ s time resolution. The voltage of the photomultiplier was automatically selected and kept constant during each set of experiments. The fluorescence intensity kinetics after the osmotic shock was recorded with logarithmically spaced time points to better resolve faster processes. For noise reduction, multiple acquisitions (three for slow kinetics and nine for fast kinetics) were performed for each experimental condition. Complete stopped-flow settings and acquired data processing are described in M. Gabba et al. (manuscript in preparation).

Reporting summary. Further information on research design is available in the Nature Research Reporting Summary linked to this article.

\section{Data availability}

All data is available in the main text or supplementary materials. All data and materials used in the analysis are available upon request to the lead author.

\section{Code availability}

All code used in the analysis is available upon reasonable request.

Received: 20 July 2019 Accepted: 2 September 2019

Published online: 18 September 2019

\section{References}

1. Blain, J. C. \& Szostak, J. W. Progress toward synthetic cells. Annu. Rev. Biochem. 83, 615-640 (2014)

2. Luisi, P. L., Ferri, F. \& Stano, P. Approaches to semi-synthetic minimal cells: a review. Naturwissenschaften 93, 1-13 (2006).

3. Forster, A. C. \& Church, G. M. Towards synthesis of a minimal cell. Mol. Syst. Biol. 2, 1-10 (2006).

4. Hutchison, C. A. et al. Design and synthesis of a minimal bacterial genome. Science 351, aad6253-1-aad6253-11 (2016).

5. Hoshika, S. et al. Hachimoji DNA and RNA: a genetic system with eight building blocks. Science 363, 884-887 (2019).

6. van Nies, P. et al. Self-replication of DNA by its encoded proteins in liposomebased synthetic cells. Nat. Commun. 9, 1-12 (2018).

7. Swank, Z., Laohakunakorn, N. \& Maerkl, S. J. Cell-free gene-regulatory network engineering with synthetic transcription factors. Proc. Natl Acad. Sci. USA 116, 5892-5901 (2019).

8. Ichihashi, N. et al. Darwinian evolution in a translation-coupled RNA replication system within a cell-like compartment. Nat. Commun. 4, 1-7 (2013).

9. Loose, M. \& Mitchison, T. J. The bacterial cell division proteins FtsA and FtsZ self-organize into dynamic cytoskeletal patterns. Nat. Cell Biol. 16, 38-46 (2014).

10. Exterkate, M., Caforio, A., Stuart, M. C. A. \& Driessen, A. J. M. Growing membranes in vitro by continuous phospholipid biosynthesis from free fatty acids. ACS Synth. Biol. 7, 153-165 (2018).

11. Bhattacharya, A., Brea, R. J., Niederholtmeyer, H. \& Devaraj, N. K. A minimal biochemical route towards de novo formation of synthetic phospholipid membranes. Nat. Commun. 10, 1-8 (2019).

12. Kuruma, Y., Stano, P., Ueda, T. \& Luisi, P. L. A synthetic biology approach to the construction of membrane proteins in semi-synthetic minimal cells. Biochim. Biophys. Acta, Biomembranes 1788, 567-574 (2009).

13. Osawa, M. \& Erickson, H. P. Liposome division by a simple bacterial division machinery. Proc. Natl Acad. Sci. USA 110, 11000-11004 (2013).

14. Terasawa, H., Nishimura, K., Suzuki, H., Matsuura, T. \& Yomo, T. Coupling of the fusion and budding of giant phospholipid vesicles containing macromolecules. Proc. Natl Acad. Sci. USA 109, 5942-5947 (2012).

15. Karzbrun, E., Tayar, A. M., Noireaux, V. \& Bar-Ziv, R. H. Programmable on-chip DNA compartments as artificial cells. Science 345, 829-832 (2014).

16. Sokolova, E. et al. Enhanced transcription rates in membrane-free protocells formed by coacervation of cell lysate. Proc. Natl Acad. Sci. USA 110, 11692-11697 (2013).

17. Zepik, H. H., Blöchliger, E. \& Luisi, P. L. A chemical model of homeostasis. Angew. Chem. Int. Ed. 40, 199-202 (2001).

18. Morrow, S. M., Colomer, I. \& Fletcher, S. P. A chemically fuelled selfreplicator. Nat. Commun. 10, 1-9 (2019).

19. Shimizu, Y. et al. Cell-free translation reconstituted with purified components. Nat. Biotechnol. 19, 751-755 (2001).

20. Noireaux, V., Maeda, Y. T. \& Libchaber, A. Development of an artificial cell, from self-organization to computation and self-reproduction. Proc. Natl Acad. Sci. USA 108, 3473-3480 (2011).
21. Matsuura, T. et al. Effects of compartment size on the kinetics of intracompartmental multimeric protein synthesis. ACS Synth. Biol. 1, 431-437 (2012).

22. Noireaux, V. \& Libchaber, A. A vesicle bioreactor as a step toward an artificial cell assembly. Proc. Natl Acad. Sci. USA 101, 17669-17674 (2004).

23. Schwander, T. et al. A synthetic pathway for the fixation of carbon dioxide in vitro. Science 354, 900-904 (2016).

24. Patel, A. et al. ATP as a biological hydrotrope. Science 356, 753-756 (2017).

25. Milo, R. \& Phillips, R. Cell biology by the Numbers. (Garland Science, 2015).

26. Opgenorth, P. H., Korman, T. P., Iancu, L. \& Bowie, J. U. A molecular rheostat maintains ATP levels to drive a synthetic biochemistry system. Nat. Chem. Biol. 13, 938-942 (2017).

27. Lee, K. Y. et al. Photosynthetic artificial organelles sustain and control ATPdependent reactions in a protocellular system. Nat. Biotechnol. 36, 530-535 (2018).

28. Berhanu, S., Ueda, T. \& Kuruma, Y. Artificial photosynthetic cell producing energy for protein synthesis. Nat. Commun. 10, 1-10 (2019).

29. Novák, L. et al. Arginine deiminase pathway enzymes: evolutionary history in metamonads and other eukaryotes. BMC Evol. Biol. 16, 1-14 (2016).

30. Driessen, A. J. M., Poolman, B., Kiewiet, R. \& Konings, W. N. Arginine transport in Streptococcus lactis is catalyzed by a cationic exchanger. Proc. Natl Acad. Sci. USA 84, 6093-6097 (1987).

31. Van der Heide, T., Stuart, M. C. A. \& Poolman, B. On the osmotic signal and osmosensing mechanism of an $\mathrm{ABC}$ transport system for glycine betaine. EMBO J. 20, 7022-7032 (2001)

32. Tantama, M., Martínez-François, J. R., Mongeon, R. \& Yellen, G. Imaging energy status in live cells with a fluorescent biosensor of the intracellular ATPto-ADP ratio. Nat. Commun. 4, 2550 (2013).

33. Bates, R. G. \& Pinching, G. D. Acidic dissociation constant of ammonium ion at $0^{\circ}$ to $50{ }^{\circ} \mathrm{C}$, and the base strength of ammonia. J. Res. Natl. Bur. Stand. 42, 419-430 (1949).

34. Record, M. T., Courtenay, E. S., Cayley, D. S. \& Guttman, H. J. Responses of E coli to osmotic stress: large changes in amounts of cytoplasmic solutes and water. Trends Biochem. Sci. 23, 143-148 (1998).

35. Boersma, A. J., Zuhorn, I. \& Poolman, B. A sensor for quantification of macromolecular crowding in living cells. Nat. Meth. 12, 227-229 (2015)

36. Van den Berg, J., Boersma, A. J. \& Poolman, B. Microorganisms maintain crowding homeostasis. Nat. Rev. Microbiol. 15, 309-318 (2017).

37. Wood, J. M. Bacterial osmoregulation: a paradigm for the study of cellular homeostasis. Annu. Rev. Microbiol. 65, 215-238 (2011).

38. Bourot, S. et al. Glycine betaine-assisted protein folding in a lysA mutant of Escherichia coli. J. Biol. Chem. 275, 1050-1056 (2000).

39. Stadmiller, S. S., Gorensek-Benitez, A. H., Guseman, A. J. \& Pielak, G. J. Osmotic shock induced protein destabilization in living cells and its reversal by glycine betaine. J. Mol. Biol. 429, 1155-1161 (2017).

40. Geertsma, E. R., Nik Mahmood, N. A. B., Schuurman-Wolters, G. K. \& Poolman, B. Membrane reconstitution of $\mathrm{ABC}$ transporters and assays of translocator function. Nat. Protoc. 3, 256-266 (2008).

41. Biemans-Oldehinkel, E., Mahmood, N. A. B. N. \& Poolman, B. A sensor for intracellular ionic strength. Proc. Natl Acad. Sci. USA 103, 10624-10629 (2006).

42. Patzlaff, J. S., Van der Heide, T. \& Poolman, B. The ATP/substrate stoichiometry of the ATP-binding cassette (ABC) transporter OpuA. J. Biol. Chem. 278, 29546-29551 (2003).

43. Sikkema, H. R., Gaastra, B. F., Pols, T. \& Poolman, B. Cell fueling and metabolic energy conservation in synthetic cells. ChemBioChem 20, https://doi.org/10.1002/cbic.201900398 (2019).

44. Berntsson, R. P. A. Structure and Function of Substrate-Binding Domains of ABC-Transporters, Thesis, University of Groningen, Chapter 3, 49-65 (2010).

45. Kuipers, O. P., de Ruyter, P. G. G. A., Kleerebezem, M. \& de Vos, W. M. Quorum sensing-controlled gene expression in lactic acid bacteria. J. Biotechnol. 64.1, 15-21 (1998).

46. Geertsma, E. R. \& Poolman, B. High-throughput cloning and expression in recalcitrant bacteria. Nat. Meth. 4, 705-707 (2007).

47. Nørholm, M. H. H. A mutant Pfu DNA polymerase designed for advanced uracil-excision DNA engineering. BMC Biotech. 10, 1-7 (2010).

48. Noens, E. E. E., Kaczmarek, M. B., Zygo, M. \& Lolkema, J. S. ArcD1 and ArcD2 arginine/ornithine exchangers encoded in the arginine deiminase pathway gene cluster of Lactococcus lactis. J. Bacteriol. 197.22, 3545-3553 (2015).

49. Knipp, M. \& Vašák, M. A colorimetric 96-well microtiter plate assay for the determination of enzymatically formed citrulline. Anal. Biochem. 286.2, 257-264 (2000).

50. Slotboom, D. J., Duurkens, R. H., Olieman, K. \& Erkens, G. B. Static light scattering to characterize membrane proteins in detergent solution. Methods 46, 73-82 (2008). 
51. Rigaud, J.-L., Pitard, B. \& Levy, D. Reconstitution of membrane proteins into liposomes: application to energy-transducing membrane proteins. Biochim. Biophys. Acta, Bioenerg. 1231.3, 223-246 (1995).

52. Stuart, M. C. A. \& Boekema, E. J. Two distinct mechanisms of vesicle-tomicelle and micelle-to-vesicle transition are mediated by the packing parameter of phospholipid-detergent systems. Biochim Biophys. Acta $\mathbf{1 7 6 8}$, 2681-2689 (2007).

53. Pudlik, A. M. \& Lolkema, J. S. Rerouting citrate metabolism in Lactococcus lactis to citrate-drive transamination. Appl. Environ. Microbiol. 78.18 6665-6673 (2012).

54. Kano, K. \& Fendler, J. H. Pyranine as a sensitive $\mathrm{pH}$ probe for liposome interiors and surfaces $\mathrm{pH}$ gradients across phospholipid vesicles. Biochim. Biophys. Acta 509, 289-299 (1978).

\section{Acknowledgements}

We thank Giorgos Gouridis for the construction of the pNZarcA and pNZarcB vectors, Marc Stuart for assistance with the cryo-EM measurements, Cecile Deelman-Driessen for enzyme assays, Michiel Punter for assistance with data fitting, Dirk-Jan Slotboom and Juke Lolkema for discussions, and Wilhelm Huck and Ian Booth for critical reading of the paper. The work was funded by an ERC Advanced Grant (ABCvolume; \#670578) and the Netherlands Organization for Scientific Research programs TOP-PUNT (\#13.006) and Gravitation (BaSyC).

\section{Author contributions}

B.G., B.P., H.S., T.P., and W.S. designed the research; B.G., H.S., T.P., and W.S. performed most of the research; S.S. purified enzymes; J.F. performed the stopped-flow measurements; B.G., B.P., H.S., T.P., and W.S. analyzed data; and B.G., B.P., H.S., and T.P. wrote the paper.

\section{Additional information}

Supplementary Information accompanies this paper at https://doi.org/10.1038/s41467019-12287-2.

Competing interests: The authors declare no competing interests.

Reprints and permission information is available online at http://npg.nature.com/ reprintsandpermissions/

Peer review information Nature Communications thanks Kwanwoo Shin and the other, anonymous, reviewer(s) for their contribution to the peer review of this work. Peer reviewer reports are available.

Publisher's note Springer Nature remains neutral with regard to jurisdictional claims in published maps and institutional affiliations.

(c) (i) Open Access This article is licensed under a Creative Commons Attribution 4.0 International License, which permits use, sharing, adaptation, distribution and reproduction in any medium or format, as long as you give appropriate credit to the original author(s) and the source, provide a link to the Creative Commons license, and indicate if changes were made. The images or other third party material in this article are included in the article's Creative Commons license, unless indicated otherwise in a credit line to the material. If material is not included in the article's Creative Commons license and your intended use is not permitted by statutory regulation or exceeds the permitted use, you will need to obtain permission directly from the copyright holder. To view a copy of this license, visit http://creativecommons.org/ licenses/by/4.0/.

(C) The Author(s) 2019 